\title{
Nature and Fate of Proliferative Cells in the Hippocampal Dentate Gyrus During the Life Span of the Rhesus Monkey
}

\author{
Maryellen F. Eckenhoff and Pasko Rakic \\ Section of Neuroanatomy, Yale University School of Medicine, New Haven, Connecticut 06510
}

\begin{abstract}
The nature of proliferative cells in the subgranular zone (SGZ) of the hippocampal region and the fate of their progeny was analyzed by ${ }^{3} \mathrm{H}$-thymidine ( ${ }^{3} \mathrm{H}-\mathrm{TdR}$ ) autoradiography combined with immunocytochemistry at the light and electron microscopic levels in 18 rhesus monkeys ranging in age from late gestation to 17 years. Our analysis indicates that, during the last quarter of gestation and the first 3 postnatal months, the SGZ produces both glial and neuronal cells. These 2 major classes of cells originate from the 2 precursor lines and, following their mitotic division, migrate to the granular layer. During the juvenile period (4-6 months of age), neuronal production tapers off and most postmitotic cells remaining within the SGZ differentiate into glial elements. In postpubertal animals ( 3 years and older), the ${ }^{3} \mathrm{H}-\mathrm{TdR}$-labeled cells in the dentate gyrus belong to several non-neuronal classes. The largest group was immunoreactive to the glial fibrillary acidic protein (GFAP) at both the light and electron microscopic levels, indicating their astrocytic nature. The remaining ${ }^{3} \mathrm{H}$-TdR-labeled, GFAP-negative cells had ultrastructural characteristics of elther microglia, oligodendroglia, or their progenitory stem cells. Therefore, there is a continuing addition and/or turnover of the glial cells in the dentate gyrus of sexually mature monkeys, but, in contrast to the massive neurogenesis reported in adult rodents, the production of new neurons could not be detected after puberty. The significance of a stable population of neurons in the hippocampal formation of mature primates is discussed in relation to its possible function in memory.
\end{abstract}

During embryonic stages of the primate telencephalon, both neurons and glial cells are produced concommitantly in the proliferative ventricular and subventricular zones lining lateral ventricles (Rakic, 1975, 1981; Levitt et al., 1981). Towards the end of development, production of neurons tapers off, while gliogenesis increases (Levitt et al., 1983): In most regions of the primate cerebrum the process of neurogenesis stops before the time of birth (Rakic, 1974, 1985a). However, this simple rule is modified in the hippocampal region in several important respects. In the developing dentate gyrus, young granule cells

\footnotetext{
Received June 8, 1987; revised Dec. 21, 1987; accepted Dec. 22, 1987.

This study was supported by USPHS Grant NS14841 and program project NS22807. Rhesus monkeys were obtained from breeding colonies at Yale University School of Medicine and New England Regional Primate Research Center, Southborough, MA. We are grateful to Lawrence Eng for generously providing the antiserum to GFAP, Joe Musco for his excellent technical assistance, and D. P. Seghal for help with surgery and postoperative care of animals.

Correspondence should be addressed to Dr. Pasko Rakic, Section of Neuroanatomy, Yale University School of Medicine, 333 Cedar Street, New Haven, CT 06510.

Copyright (C) 1988 Society for Neuroscience $0270-6474 / 88 / 082729-19 \$ 02.00 / 0$
}

are initially generated exclusively in the ventricular zone (Nowakowski and Rakic, 1981). After their last cell division in this zone, postmitotic cells migrate along the radial glial fibers to their final position in the dentate plate (incipient granular layer), which eventually differentiates and transforms into the mature granular layer of the dentate gyrus (Nowakowski and Rakic, 1979; Eckenhoff and Rakic, 1984). Well before the end of gestation, the ventricular zone in the sector subserving the dentate gyrus disappears, but proliferation of cells continues in the subgranular zone (SGZ) situated below the developing granule cell layer (Nowakowski and Rakic, 1979; Eckenhoff and Rakic, 1984). This newly formed proliferative center can be considered a displaced subventricular zone of the hippocampal formation that produces both neurons and glial cells destined for the dentate gyrus during the postnatal phase of development (Nowakowski and Rakic, 1981; Sidman and Rakic, 1982; Duffy and Rakic, 1983).

Neurogenesis and gliogenesis in the SGZ of the dentate gyrus lasts for several months after birth in a variety of mammalian species (Angevine, 1965; Caviness, 1973; Schlessinger et al., 1975; Kaplan and Hinds, 1977; Gueneau et al., 1982), including primates (Rakic and Nowakowski, 1981). However, the precise time point when neuronal production in this region stops has not been clarified. For instance, it has been reported that in the rat and rabbit, neurogenesis in the dentate gyrus continues throughout adult life (Bayer, 1982, 1985; Bayer et al., 1982; Gueneau et al., 1982; Kaplan and Bell, 1984; Crespo et al., 1986). In contrast, the addition of neurons has been seen only during restricted developmental stages in mice (Angevine, 1965), cats (Wyss and Sripanidkulchai, 1985), and monkeys (Nowakowski and Rakic, 1981). Because of these conflicting results, we were compelled to examine the composition and proliferative outcome of this zone in primates with modern neurobiological techniques. The developmental history of this zone and the fate of its cells throughout the entire life cycle has not been determined in any primate, even though the issues in question have considerable implications for understanding hippocampal development and its possible memory function in humans (Squire and Zola-Morgan, 1983; Lynch and Baudry, 1984). In the present study, we examined the composition of the SGZ of the dentate gyrus of monkeys ranging in age from the late fetal stages to 17 years employing ${ }^{3} \mathrm{H}$-thymidine autoradiography to detect DNA synthesis and electron microscopy and immunocytochemistry to determine the morphology of late-generated cells and the presence of glial cell-specific antibodies in this region.

\section{Materials and Methods}

Eighteen rhesus monkeys (Macaca mulatta) ranging in age from embryonic day 140 (E140) to adult (3-17 years of age) were used in this 
Table 1. The age of animals, schedule of ${ }^{3} \mathrm{H}-\mathrm{TdR}$ injections and methods employed

\begin{tabular}{|c|c|c|c|c|c|}
\hline \multicolumn{4}{|l|}{ LM-ARA } & \multirow[b]{2}{*}{$\begin{array}{l}\text { EM-GFAP } \\
\text { Age }\end{array}$} & \multirow{2}{*}{$\begin{array}{l}\text { GFAP + } \\
\text { ARA } \\
\text { Age }\end{array}$} \\
\hline Case & Age & $\begin{array}{l}\text { Number of } \\
\text { injections }\end{array}$ & Interval & & \\
\hline 022070 & E140-E140.1 & 1 & $1 \mathrm{~d}$ & & \\
\hline 073070 & E140-P57 & 1 & $3 \mathrm{mo}$ & & \\
\hline 030983 & & & & E144 & \\
\hline 090969 & P2-P2.1 & 1 & $1 \mathrm{~d}$ & & \\
\hline $021177 \mathrm{~A}$ & P1-P73 & 1 & $2^{1 / 2} \mathrm{mo}$. & & \\
\hline 030474 & P34-P34.1 & 1 & $\mathrm{ld}$ & & \\
\hline 010673 & P32-P96 & 1 & $2 \mathrm{mo}$. & & \\
\hline 032577 & P60-P60.1 & 1 & $1 \mathrm{~d}$ & & \\
\hline $021177 \mathrm{~B}$ & P60-P126 & 1 & $2 \mathrm{mo}$. & & \\
\hline 050477 & P96-P96.1 & 1 & $1 \mathrm{~d}$ & & \\
\hline 031777 & P90-P155 & 1 & $2 \mathrm{mo}$ & & \\
\hline 022875 & P184-P184.1 & 1 & $1 \mathrm{~d}$ & & \\
\hline 030783 & P149-P184 & 1 & $5 \mathrm{wk}$ & P184 & P184 \\
\hline 031683 & P507-P549 & 1 & $6 \mathrm{wk}$ & P549 & P549 \\
\hline 112883 & $5 \mathrm{yr}$ & $7^{a}$ & $3 \mathrm{mo}$. & $5 \mathrm{yr}$ & $5 \mathrm{yr}$ \\
\hline 012980 & $10 \mathrm{yr}$ & $3^{b}$ & $3 \mathrm{yr}$ & & \\
\hline 012376 & $10 \mathrm{yr}$ & $5^{c}$ & $14 d$ & & \\
\hline 021583 & $17 \mathrm{yr}$ & 1 & $6 \mathrm{yr}$ & $17 \mathrm{yr}$ & $17 \mathrm{yr}$ \\
\hline
\end{tabular}

${ }^{a}$ One injection/day for 7 consecutive days.

${ }^{b}$ Injections over a 2 year period.

c Injections over a 3 year period.

Abbreviations: ARA, autoradiography; E, embryonic day; EM, electron microscopy; GFAP, immunocytochemistry using glial fibrillary acidic protein; LM, light microscopy; $\mathrm{P}$, postnatal day.

study (Table 1). Breeding of the animals and dating of pregnancies were performed as described previously (Rakic, 1973). Normal gestation in the rhesus monkey lasts about $165 \mathrm{~d}(\mathrm{E} 165=\mathrm{P} 0)$. In order to determine the site of cell proliferation, 6 animals were injected intravenously with a single dose of $5-10 \mathrm{mCi} / \mathrm{kg}$ of ${ }^{3} \mathrm{H}$-thymidine $\left({ }^{3} \mathrm{H}-\mathrm{TdR}, 40-60 \mathrm{Ci} / \mathrm{mm}\right.$ specific activity) and sacrificed $1 \mathrm{hr}$ later. Eleven additional animals were injected 1-7 times with the same doses of ${ }^{3} \mathrm{H}$-TdR and allowed to survive from 5 weeks to 2 years. This interval allows the cells generated at the time of injection to reach their final position and express their definitive phenotype. One animal was used exclusively for EM immunocytochemistry to demonstrate glial and neuronal populations at E144. The age of each animal in Table 1 is designated by the age in embryonic (E) or postnatal $(\mathrm{P})$ days at the time of cxposure to ${ }^{3} \mathrm{H}-\mathrm{TdR}$, followed by a hyphen and the age at the time of sacrifice.

All animals were initially tranquilized with ketamine $(5 \mathrm{mg} / \mathrm{kg})$ and then immediately prior to perfusion anesthetized with sodium phenobarbitol $(40 \mathrm{mg} / \mathrm{kg})$. The animals were perfused through the left ventricle of the heart with phosphate buffer $(\mathrm{pH} 7.4)$ containing $1 \%$ paraformaldehyde and $1.25 \%$ glutaraldehyde. The brains were removed and divided into left and right hemispheres. The hippocampal formation of the right hemisphere of 5 animals was dissected into $1-\mathrm{mm}$-thick coronal slices and immediately processed for EM immunocytochemistry. The remainder of the right hemisphere and the entire left hemisphere were immersed in fixative overnight at $4^{\circ} \mathrm{C}$. The next day, the left hemispheres of 17 animals were processed for autoradiography and the remainder of the brain prepared for ultrastructural analysis for other projects.

Autoradiography. The left hemispheres of 17 brains were dehydrated, embedded in paraffin, and serially sectioned at $8 \mu \mathrm{m}$. The sections were mounted on gelatin-subbed slides, defatted in a series of graded alcohols and xylene, and dipped in Kodak NTB2 emulsion. The emulsion-coated sections were stored in the refrigerator for $10-18$ weeks before developing in Kodak D-19 developer, fixed with 24\% sodium thiosulfate, and stained with cresyl violet. Autoradiograms prepared from coronal sections through the hippocampus were examined with a Zeiss photomicroscope using Nomarsky optics, photographed using a $63 \times$ objective, and photographically enlarged to $750 \times$. Heavily labeled neurons, representing cells that had undergone final division on the day of ${ }^{3} \mathrm{H}-\mathrm{TdR}$ injection, were classified as those containing more than half the maximum number of silver grains observed over the most intensely radiolabeled cells in a given case (Rakic, 1973).
Immunocytochemistry. The hippocampal formations dissected from 5 brains were processed for the immunocytochemical localization of glial fibrillary acidic protein (GFAP) at the light and electron microscopic (EM) levels. This protein is considered to be specific for the astroglial cell line and can be detected by the peroxidase-antiperoxidase method in the developing primate brain (Eng and Rubinstein, 1978; Levitt and Rakic, 1980; Levitt et al., 1981; Choi, 1986). The hipnocampal formation was cut coronally into anterior, middle, and posterior blocks. Each block was washed in $0.1 \mathrm{~m}$ trizma buffered saline (TBS),

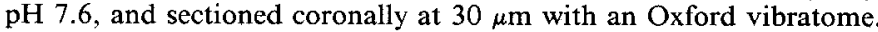
The Vectastain $A B C$ immunoperoxidase staining procedure (Vector Laboratories, Burlingame, CA) was used for the localization of GFAP. The vibratome sections were incubated with diluted normal goat serum for 30 min prior to an overnight incubation at room temperature with a 1:1000 dilution of the rabbit primary antisera directed against GFAP isolated from bovine spinal cord (Eng and Rubinstein, 1978) diluted in buffer containing normal goat serum. Control sections were incubated in normal goat serum in place of the primary antibody and left overnight in the refrigerator at $4^{\circ} \mathrm{C}$. The next day, the sections were washed with TBS and then incubated with the biotinylated antibody for $45 \mathrm{~min}$ followed by a brief wash with TBS and then a 45-60 min incubation with the avidin-biotin complex. The sections were washed before incubating for $5 \mathrm{~min}$ in diaminobenzidine (DAB) followed by a 5-8 $\mathrm{min}$ incubation in $\mathrm{DAB}$ containing $0.3 \%$ hydrogen peroxide. The sections were washed and arbitrarily divided up for light and electron microscopic examination. Sections for light microscopy were mounted on gelatin-coated slides, defatted in graded alcohols and xylenes, and either stained with cresyl violet and coverslipped or processed for autoradiography as described above.

Electron microscopy. The remaining vibratome sections, stained for the immunocytochemical localization of GFAP, were prepared for electron microscopy. The sections were first washed with $0.1 \mathrm{M}$ phosphate buffer with $5 \%$ sucrose, followed by $30 \mathrm{~min}$ in $2 \%$ osmium tetroxide, washed in maleate buffer and then incubated in uranyl acetate, and washed and dehydrated in graded alcohols and propylene oxide. The sections were left overnight in a 1:1 solution of propylene oxide and a mixture of Epon 812 and Araldite 8005 (E/A). The next morning, the sections were placed in $100 \% \mathrm{E} / \mathrm{A}$ and then flat-embedded. The SGZ of the dentate gyrus was cut out from these flat sections and glued to blank blocks of Araldite before ultrathin $(0.07 \mu \mathrm{m})$ sections were cut 
for ultrastructural examination. Other blocks were cut for combined autoradiography and electron microscopy in the following manner. Since only about $3 \mu \mathrm{m}$ of the surface of the vibratome sections are labeled with the immunoperoxidase reaction product, 2 semithin sections $(0.5$ $\mu \mathrm{m})$ were cut followed by 10 ultrathin $(0.07 \mu \mathrm{m})$ sections, followed by 3 more semithin sections. The semithin sections were placed on acidcleaned slides, and the ultrathin sections were placed on Formvar-coated slot grids. The grids were lightly coated with carbon to suppress chemographic effects and provide a hydrophobic surface. Then the slides were dipped in Kodak NTB2 emulsion, and the grids were coated with a thin layer of Ilford L-4 emulsion using the expanding loop technique (Telford and Matsumura, 1969). The slides and grids were stored in a refrigerator for 6-18 months and then developed in Kodak D-19 and fixed with $24 \%$ sodium thiosulfate. The semithin sections were stained with toludine blue and examined on a Zeiss microscope. The thin sections were stained with lead citrate and examined with a JEOL 100s electron microscope. In general, the background was low and 4 silver grains over a cell nucleus was considered to demonstate ${ }^{3} \mathrm{H}-\mathrm{TdR}$ incorporation.

\section{Results}

\section{Autoradiography}

In the youngest animal examined in this study (E140), the ventricular zone of the hippocampal formation had already been exhausted and proliferative cells were observed only in the SGZ that is situated below the developing granular layer (Nowakowski and Rakic, 1981; Eckenhoff and Rakic, 1983). Although the SGZ was present in all specimens of our series, it was most prominent during late fetal life and within the first 6 months after birth.

In the fetus injected with ${ }^{3} \mathrm{H}-\mathrm{TdR}$ at E140 and sacrificed $1 \mathrm{hr}$ later (E140-E140.1), 10-12 heavily labeled cells per section were found exclusively within the SGZ (Fig. 1, $A$ and $B$ ). To determine the nature and destiny of these cells, another fetus was injected with ${ }^{3} \mathrm{H}-\mathrm{TdR}$ at the same age (E140), delivered at term (E165), and sacrificed at postnatal day 57 (E140-P57). The interval of almost 3 months that lapsed between the time of injection and the time of death in this experiment allowed cells that were in their last division at E140 to differentiate and express their phenotypic characteristics. Two classes of radiolabeled cells in the dentate gyrus of this case were observed. One class, consisting of small cells $(5-6 \mu \mathrm{m})$ with darkly stained nuclei (Fig. 1C), remained mostly in the SGZ, indicating that approximately half of the cells generated at E140 had not moved far from the site of their origin. The second class of radiolabeled cells had a larger $(9-10 \mu \mathrm{m})$, paler nucleus and a thicker rim of perikaryal cytoplasm, and were located entirely along the hilar aspect of the granular layer (Fig. 1D). These cells had typical morphological, positional, and tinctorial properties of the dentate granule cells. Therefore, our findings reveal that the SGZ at E140 produces 2 distinct classes of cells in terms of their localization, but use of the cresyl violet staining method alone could not resolve whether their nature was neuronal or glial.

Injection of a neonatal monkey with ${ }^{3} \mathrm{H}-\mathrm{TdR}$ followed by sacrifice $1 \mathrm{hr}$ later (P2-P2.1) also revealed the presence of an average of 8 heavily labeled cells in the SGZ per coronal section (Fig. 2A). The high frequency of labeled cells shows that vigorous proliferation in this zone occurs in neonatal primates. Another animal that was also injected with ${ }^{3} \mathrm{H}-\mathrm{Td} \mathrm{R}$ at birth and sacrificed $2 \frac{1}{2}$ months later (P1-P73) allowed us to follow the destiny of cells that were dividing during the neonatal period. In this specimen, we found 2 classes of heavily labeled cells, reminiscent of those observed in the E140-P57 case. However, radiolabeled cells in this animal were localized in somewhat different positions and were distributed in different proportions than in the E144-P57 specimen. The majority, approximately $80 \%$, of la- beled cells in the P1-P73 animal remained in the SGZ. These cells were characterized by small size $(6 \mu \mathrm{m})$ and dark staining with cresyl violet (Fig. $2 B$ ). The smaller proportion of radiolabeled cells were located deep in the granule cell layer. They were larger $(10-12 \mu \mathrm{m})$, both the nucleus and cytoplasm stained paler, and they had the main characteristics of granule cell neurons.

The analysis of autoradiograms prepared from animals injected with ${ }^{3} \mathrm{H}$-TdR at 1,2 , and 3 months of age and sacrificed the same day or at progressively later stages (Table 1) showed a systematic decrease in the total number of newly generated cells; from an average of 3-4 radiolabeled cells per section in the SGZ at 1 month of age to 1-2 cells per section at 3 months of age. Furthermore, in animals injected $1 \mathrm{hr}$ before sacrifice, all of the proliferative cells were located within the SGZ (Figs. $2 \mathrm{C} ; 3, A$ and $C$ ). Animals sacrified 2 months after injection revealed that, in the approximately 150 total sections examined at the 3 ages selected, radiolabeled cells remained in this region (Figs. $2 D ; 3, B$ and $D$ ), with the exception of 3 radiolabeled cells observed in the molecular layer (e.g., Fig. $3 B$ ) and 8 labeled definitive granule neurons, of which only 1 labeled granule cell was found in the P90-P155 specimen. The presence of labeled definitive granule neurons indicates that neurogenesis in monkeys continues up to at least 3 months after birth and that postmitotic cells destined to be neurons mature in less than 2 months.

Between 4 and 6 months of age, the SGZ of the dentate gyrus in the rhesus monkey becomes further attenuated. It still consists of small, darkly stained cells. The evidence for continued cell proliferation in this zone comes from the case injected with ${ }^{3} \mathrm{H}$ TdR at 6 months that was sacrificed 1 hr later (P184-P184.1). Although we found an average of one radiolabeled cell within the SGZ per section from this animal (Fig. $4 A$ ), their prospective fate could not be determined because only $1 \mathrm{hr}$ had passed between their last cell division and the time of sacrifice. However, in the specimen injected at about the same time ( 5 months) and sacrificed 5 weeks later (P149-P184), all radiolabeled cells remained in the SGZ and retained their small $(6 \mu \mathrm{m})$ size and dark tinctorial properties when counterstained with cresyl violet. Among cells labeled by the P149 injection, none acquired the larger, pale nucleus characteristic of neurons situated below the granular layer (Fig. $4 B$ ). This indicated that neurogenesis throughout the entire dentate gyrus may have stopped or at least considerably slowed down by this age.

Another experiment with a similar schedule of ${ }^{3} \mathrm{H}-\mathrm{TdR}$ injection and sacrifice was repeated in an animal at $1 \frac{1 / 2}{2}$ years of age (P507-P549). In this specimen, labeled cells were rarely observed (e.g., about 10 cells in more than 100 autoradiograms prepared from coronal sections). This signified that the number of cells produced in the SGZ had diminished even further by this age. These few late-generated cells, detected by the presence of silver grains above background level, were always small, darkly stained, and located in the SGZ; none of them had neuronal characteristics (Fig. 5A).

In the dentate gyrus of adult (postpubertal) rhesus monkeys we found an attenuated SGZ and an extremely low level of prolifcration. For example, we found only one radiolabeled cell in the SGZ in 100 coronal sections examined across the entire dentate gyrus in the 17-year-old animal that was injected with ${ }^{3} \mathrm{H}$-TdR only once (Table 1 ). To increase the probability of "catching" more dividing cells and to examine their cytological characteristics, some animals received multiple injections of ${ }^{3} \mathrm{H}$ TdR (Table 1). We used a total of 3-7 injections per animal. As expected, animals with multiple injections contained a great- 

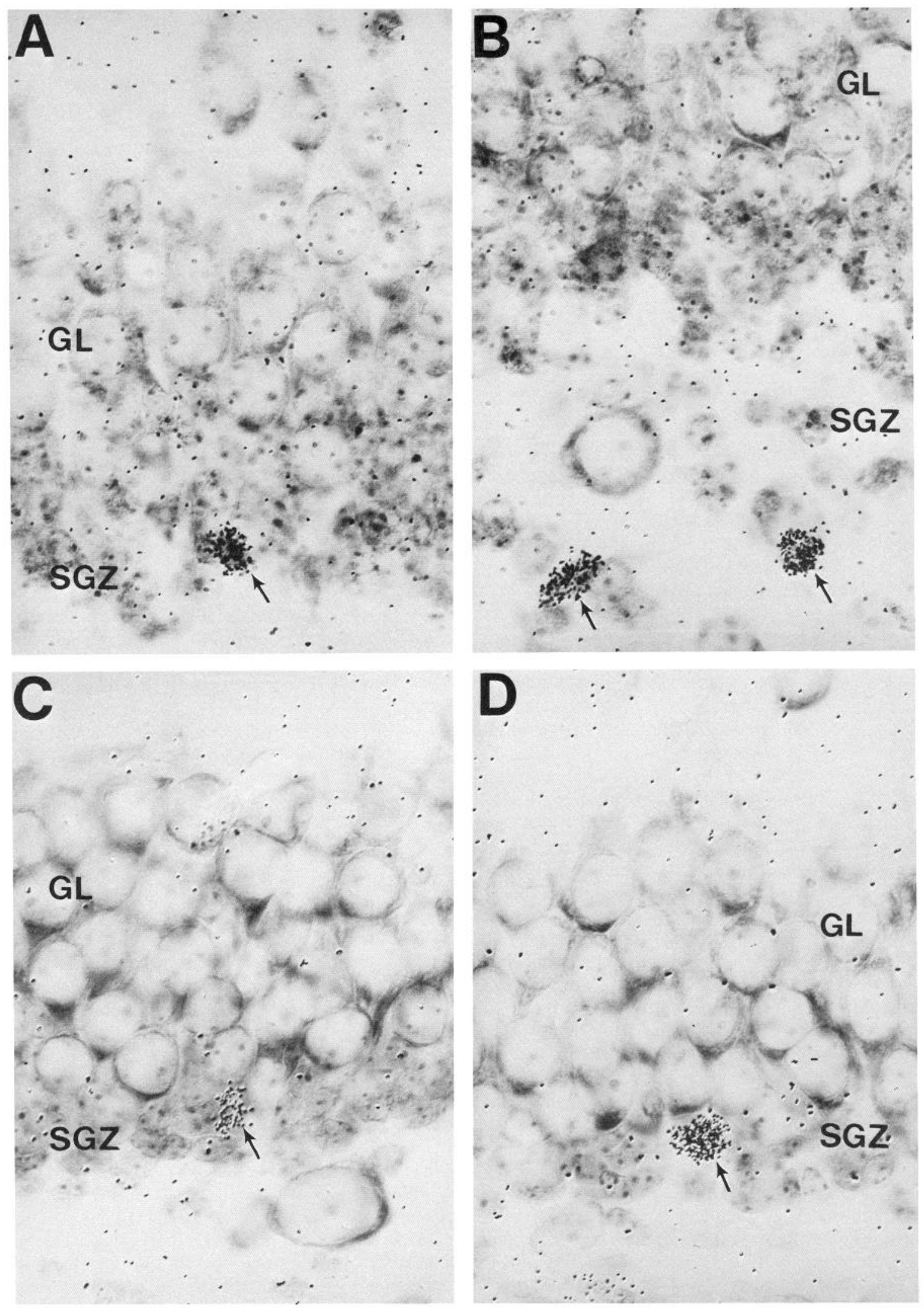

Figure 1. $A$ and B, E140-E140.1, cells generated at E140 (arrows) are found throughout the subgranular zone (SGZ) located beneath the granule cell layer $(G L)$. $C$ and $D$, E140-P57, cells generated at E140 and allowed to mature remain as small, dark-staining cells in the SGZ (2C) or possibly differentiate into larger granule cell neurons $(2 \mathrm{D}) . \times 880$. 


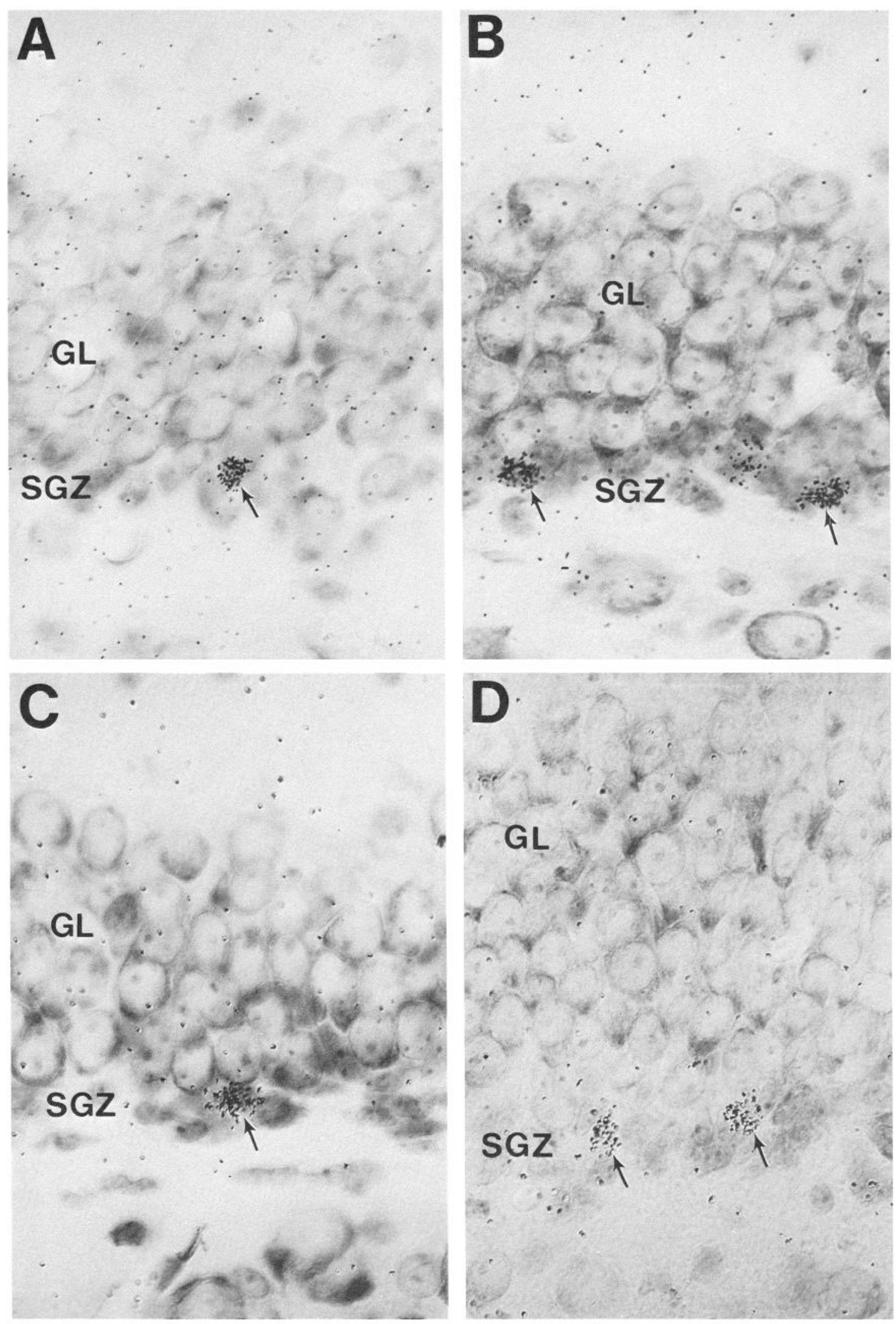

Figure 2. A, P2-P2.1, small, dark cells (arrow) are generated at birth in the subgranular zone (SGZ) below the granule cell layer (GL). B, P1-P73, the majority of cells labeled with ${ }^{3} \mathrm{H}-\mathrm{TdR}$ (arrows) are located in the SGZ and are smaller and more darkly stained than the neurons in the GL. $C$, P34-P34.1, cells produced at 1 month of age (arrow) are observed in the SGZ and are small and dark. D, P32-P96, cells born at 1 month of age (arrows) retain their small, dark appearance and their location in the SGZ. $\times 750$. 

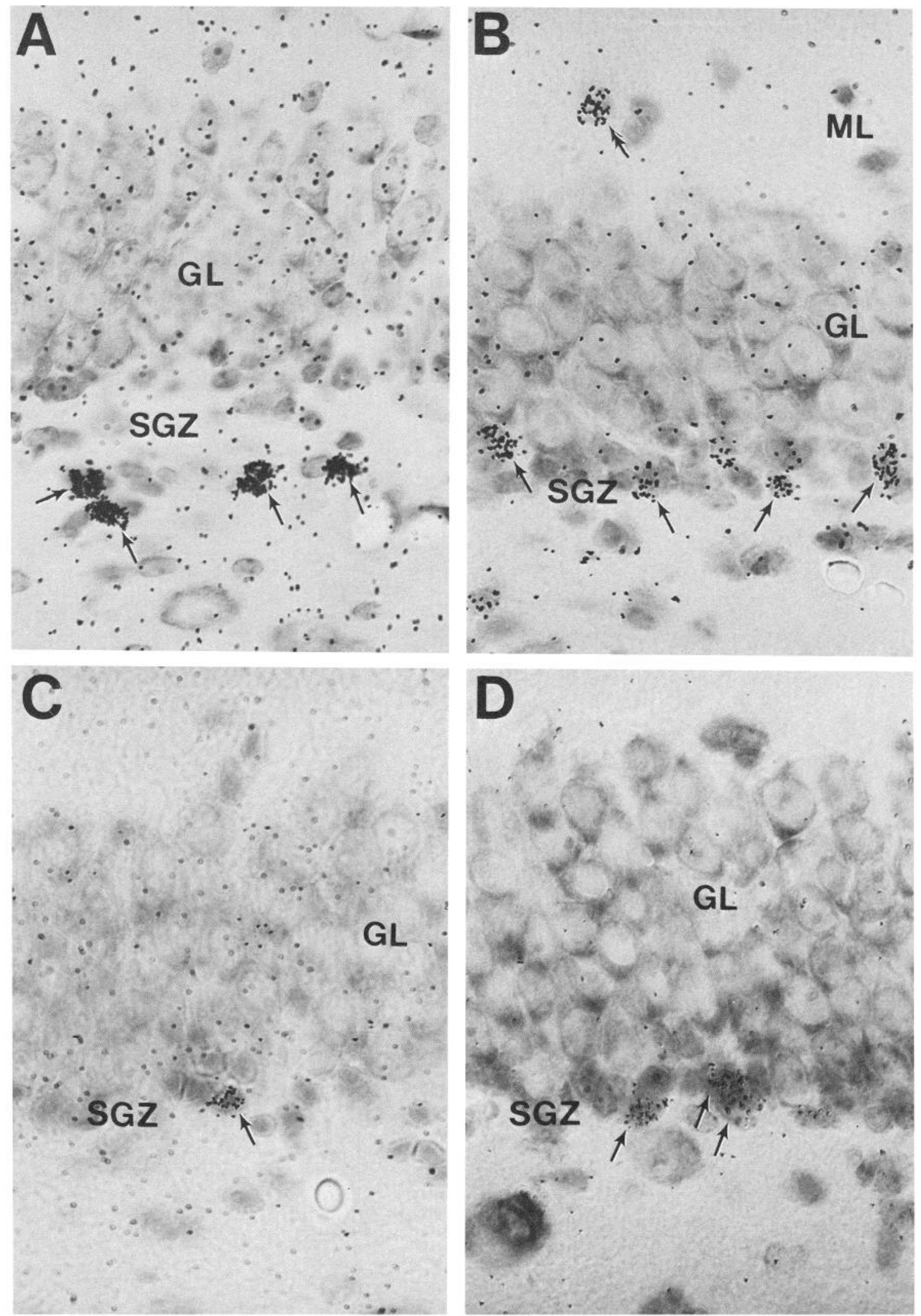

Figure 3. A, P60-P60.1, cells generated at 2 months of age (arrows) are produced in the subgranular zone (SGZ) and are characteristically small and dark. $B, \mathrm{P} 60-\mathrm{P} 126$, nearly 2 months later, these cells (arrows) are still observed in the SGZ and appear morphologically the same. In addition, an occasional labeled cell (double arrow) was observed in the molecular layer $(M L)$ ). $C$, P96-P96.1, fewer small, dark cells are being produced at 3 months of age (arrow) in the SGZ. D, P90-P155, ${ }^{3} \mathrm{H}-\mathrm{TdR}$ labeled cells (arrows) apparently remain as small, dark cells located in the SGZ. Granule cell layer, GL. ×750. 

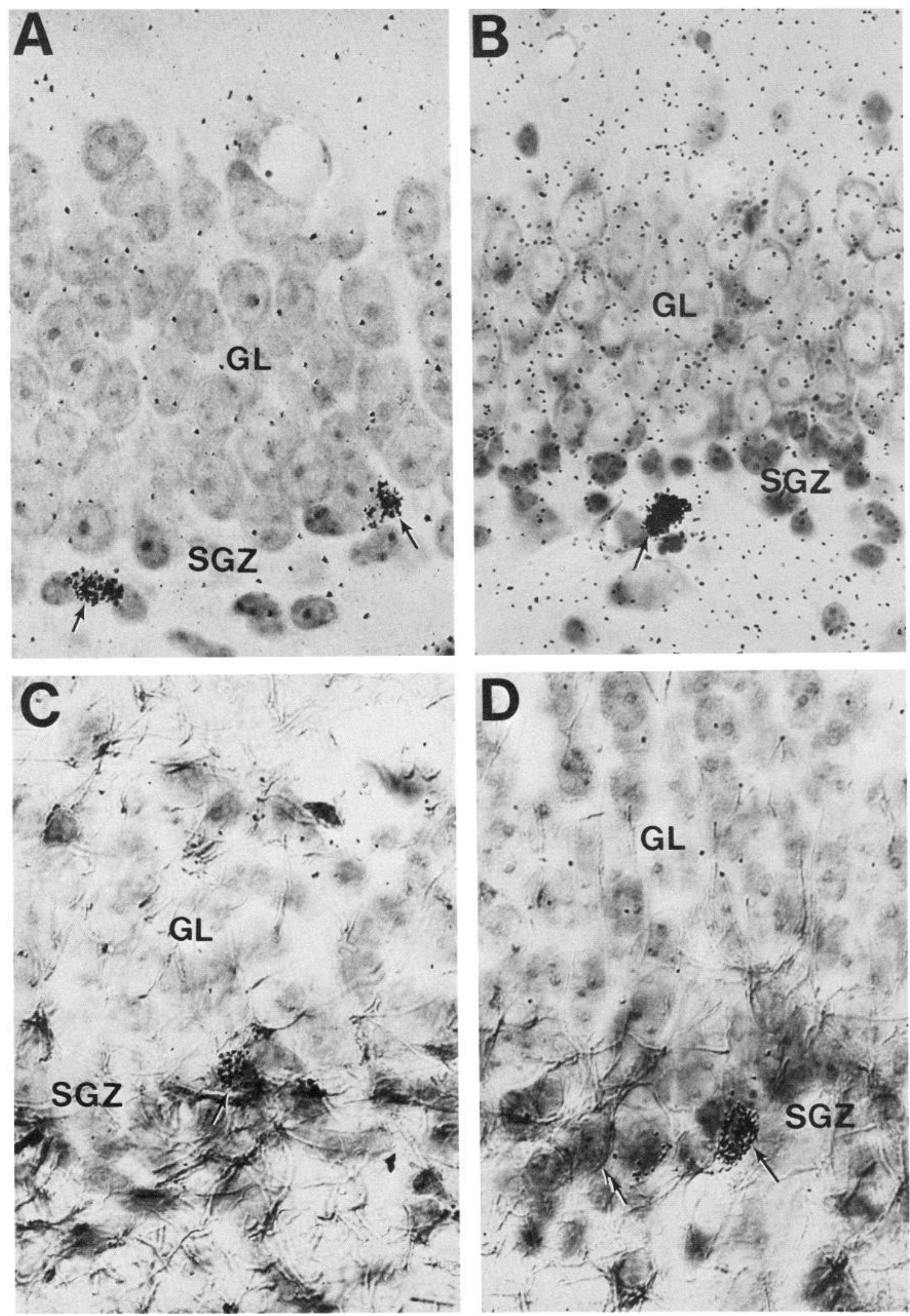

Figure 4. A, P184-P184.1, cells generated at 6 months of age (arrows) are small, dark cells located in the subgranular zone (SGZ). B, P149-P184, cells produced 6 weeks earlier (arrows) have a similar morphological appearance and location in the SGZ. C, P149-P184, combined immunocytochemical localization of GFAP and ${ }^{3} \mathrm{H}$-TdR autoradiography indicates that many of the late-generated cells in the SGZ are GFAP-positive (arrow). D, P149-P184, in addition, some GFAP-negative cells were also labeled with silver grains (arrow) in the SGZ with the same size and shape as the GFAP-positive cells (double arrow). $\times 750$. 

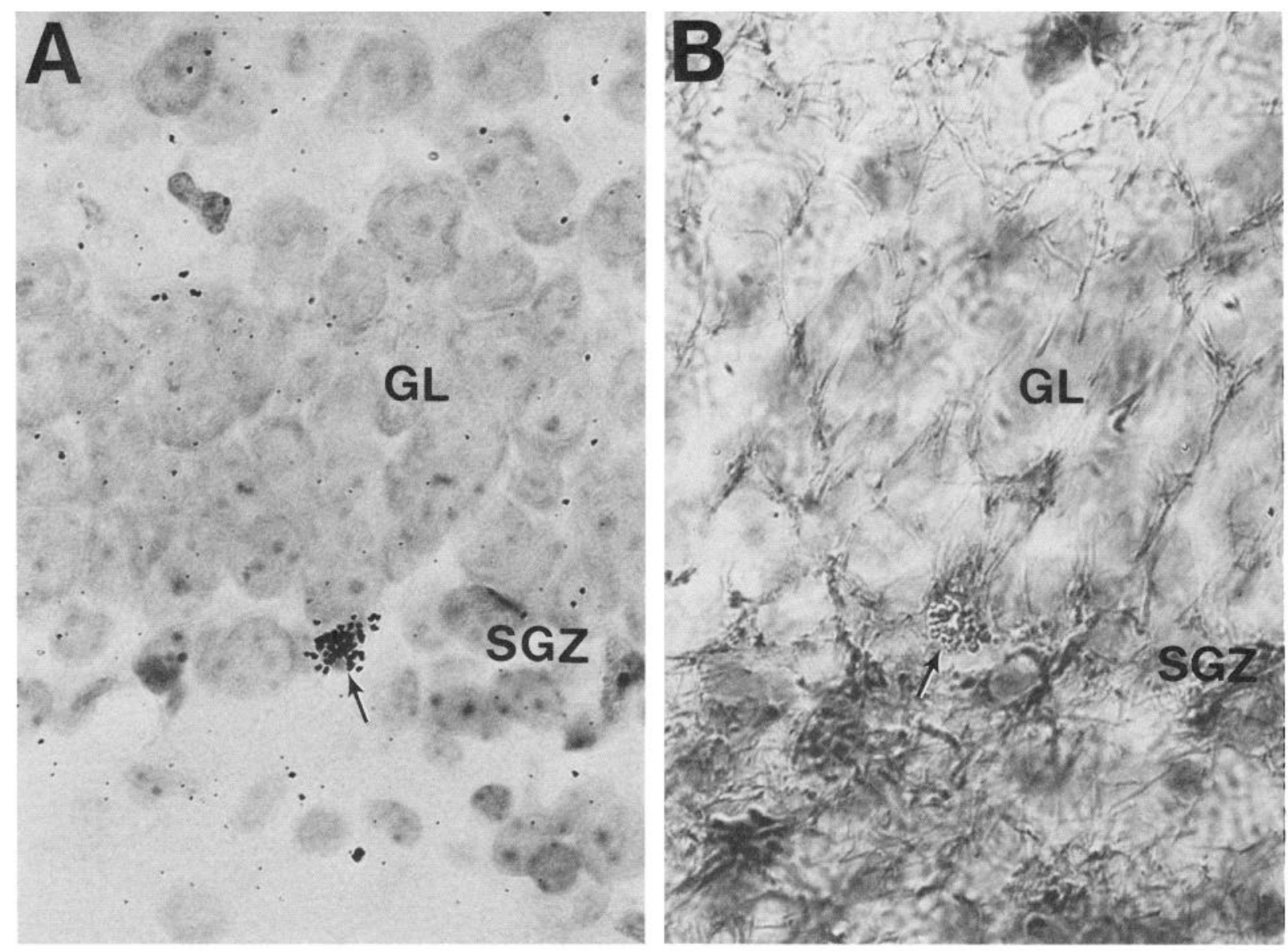

Figure 5. P507-P549, A, The few cells that are produced at about 1 1/2 years of age are the small, dark cells of the subgranular zone (SGZ; arrow). $B$, Many of these cells are GFAP-positive (arrow). The sections were counterstained with cresyl violet. Granule cell layer, $G L$. $\times 750$.

er number of intensely radiolabeled cells in the SGZ than animals receiving only a single injection, especially the animal injected once a day for 7 consecutive days (Fig. $6 \mathrm{~A}$ ), in which an average of 2 cells per 10 sections was found. All radiolabeled cells were small $(5-7 \mu \mathrm{m})$ and darkly stained by the cresyl violet. Despite the 3 month interval between injection and sacrifice, no labeled cells displayed light microscopic characteristics typical of granule cell neurons in the dentate gyrus. Because of the methodological limitation of Nissl staining, which only suggests, rather than proves, either the neuronal or glial nature of radiolabeled cells, we examined the cells in the SGZ by (1) immunocytochemistry at the electron microscopic level, (2) immunocytochemistry at the light microscopic level combined with ${ }^{3} \mathrm{H}-\mathrm{TdR}$ autoradiography, and (3) a combination of electron microscopy, immunocytochemistry, and ${ }^{3} \mathrm{H}$-TdR autoradiography. Although these methods, by nature, are not amenable to rigorous quantification, they can be used for reliably determining the nature of radiolabeled cells.

\section{Electron microscopy and immunocytochemistry}

Results from the autoradiographic analysis demonstrated that at least 2 phenotypic classes of cells are produced in the SGZ. It seems likely that these 2 classes of precursor cells produce neuronal and non-neuronal cell lines. However, because of the inherent uncertainty of light microscopic criteria for cell classification, we examined the cellular composition of the SGZ at several critical ages using immunocytochemical localization of glial fibrillary acidic protein (GFAP) at the ultrastructural level.

Examination of 45 sections from the E144 specimen demonstrated that about half of the cells comprising the SGZ at this age are GFAP-positive and therefore are probably non-neuronal (Fig. 7). The immunoreactive cells were characterized by their small size (5-6 $\mu \mathrm{m}$ nuclear diameter), the GFAP-positive cytoplasm with an abundance of organelles, and the darkly stained, densely packed nucleochromatin. The nonreactive, undifferentiated cells in the SGZ, although morphologically similar, presumably give rise to neurons. However, among these nonGFAP-reactive cells may also be some non-neuronal cells other than astroglia, such as microglia or oligodendroglia (see also Levitt et al., 1981; Kitamura et al., 1984). Thus, at least the 2 main classes of cells are produced in the SGZ at late and neonatal fetal ages-neurons and astrocytes-which possibly originate from 2 separate classes of precursors. However, the possibility of a third cell line destined to be other classes of glial cells could not be excluded by the method used in the present study.

When the SGZ was examined for the localization of GFAP at 6 months of age, approximately $75 \%$ of the small, darkly stained cells were found to be GFAP-positive (Fig. 8). None of the GFAP-negative cells in this zone had neuronal characteristics. Similar cellular composiiton has been seen in the SGZ of older animals. For example, at $1 \frac{1 / 2}{2}$ and 5 years of age, the majority of cells in the SGZ reacted with GFAP antibody (Figs. 9, 

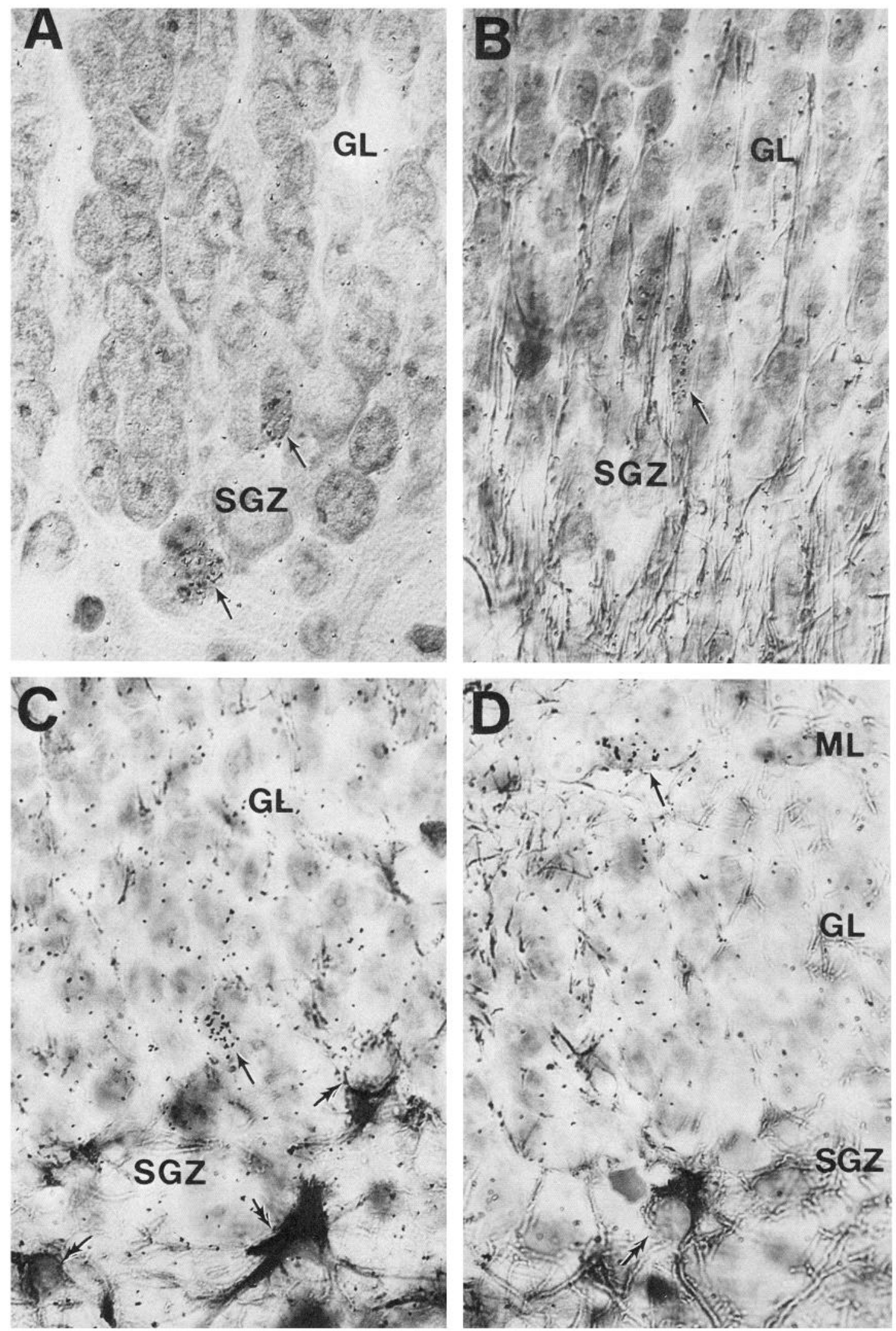

Figure 6. Five-year-old adult injected with ${ }^{3} \mathrm{H}$-thymidine for 7 consecutive days 3 months prior to sacrifice. $A$, All radiolabeled cells are small and dark (arrows) and located beneath the granule cell layer $(G L)$ in the subgranular zone $(S G Z)$. B, Combined immuncytochemistry and autoradiography indicates that many of these ${ }^{3} \mathrm{H}-\mathrm{TdR}$ labeled are GFAP-positive (arrow). $C$, Many other radiolabeled cells, however, are GFAPnegative (arrow) and are always smaller and more heavily stained with cresyl violet than the neurons in the GL. Several GFAP-positive cells can be seen in the (double arrows). D, An occasional radiolabeled cell (arrow) was found in the molecular layer $(M L)$ in the adult. This one is juxtaposed with a small blood vessel. GFAP-positive cell can be seen in the SGZ. All sections were counterstained with cresyl violet. $\times 750$. 


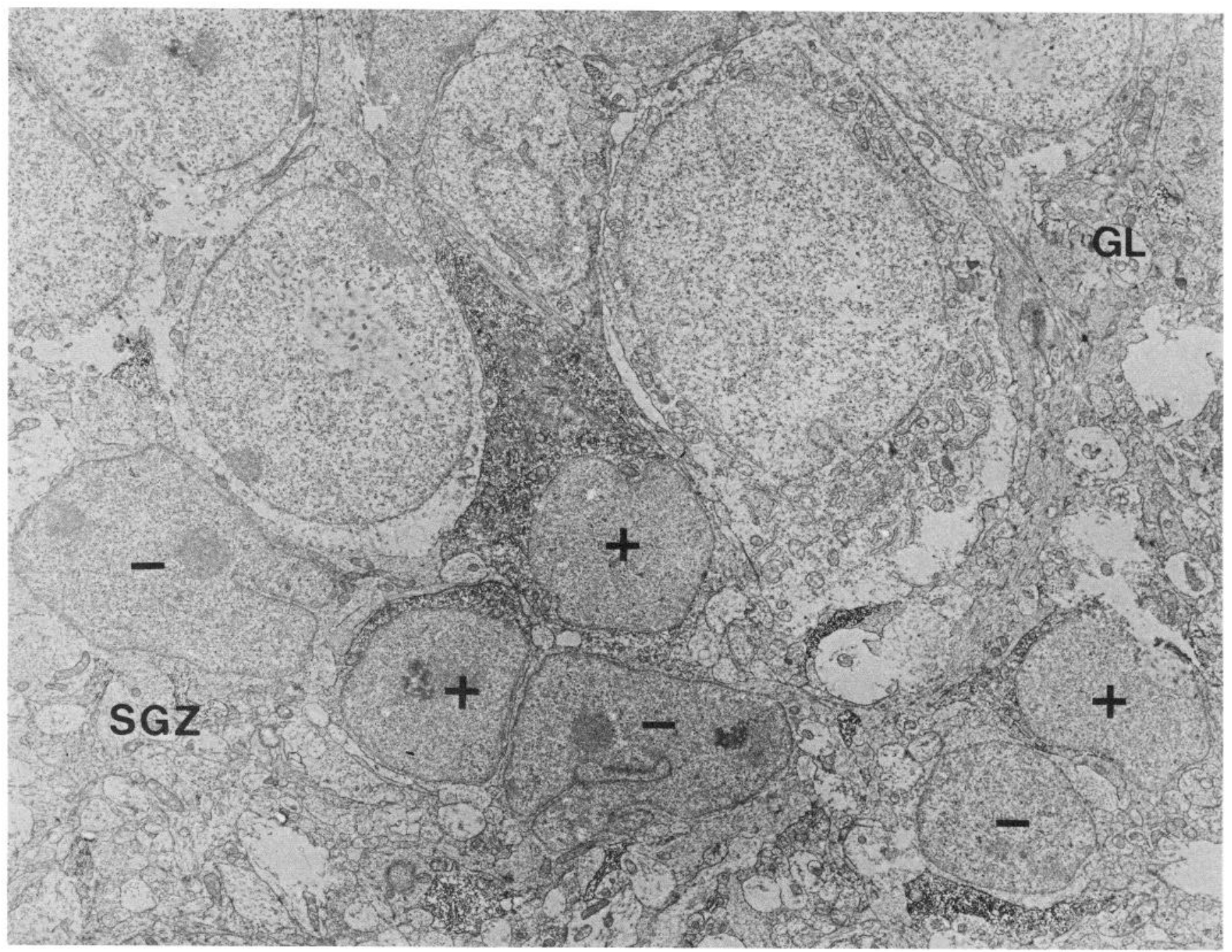

Figure 7. Ultrastructural localization of GFAP in the E144 specimen revealed that approximately half of the small, dark-staining cells in the subgranular zone $(S G Z)$ are GFAP-positive $(+)$ and half are GFAP-negative $(-)$. Large, pale mature granule cell neurons $(G C)$ are found above this zone. $\times 5000$.

10). The immunopositive cells were small (5-7 $\mu \mathrm{m})$ and oval in shape with an electron-dense and relatively homogeneous nucleus. There was an abundance of short-string rough endoplasmic reticulum in the cytoplasmic matrix. The GFAP-negative cells in the SGZ were usually similar in size but somewhat different in appearance (Fig. 9). Their cytoplasm had fewer organelles and was more electron-lucent than the GFAP-positive cells. Microtubules, but no glial fibrils, could be observed in their cytoplasm. In not a single instance could we observe synapses on the cell bodies or other neuronal characteristics of the GFAP-negative cells in this region, although the ultrathin sections were cut semiserially. Based on the ultrastructural criteria, the small nonreactive cells in the SGZ may be oligodendroglia or microglia, as previously observed in other parts of the mammalian CNS (Ichikawa and Hirata, 1982). However, some cells of the small variety with electron-dense nuclei and scanty cytoplasm may be precursors of microglia, also called resting microglia (Kitamura et al., 1984). Cells of this class are thought to have the ability to transform into both microglia and immature astroglial cells, a suggestion based on the presence of transitional forms in the developing hippocampal region of the mouse (Kitamura et al., 1984).

\section{Autoradiography and light microscopic immunocytochemistry}

Autoradiography, when used alone, has shown that proliferation of cells in the SGZ continues throughout virtually the entire adult life of the rhesus monkey, albeit at an extremely slow rate. However, the light microscopic evidence suggests that neurogenesis has ceased in this region before 6 months of age, and this is corroborated by the immunocytochemical localization of GFAP. Although both neuronal and glial cell precursors-are initially present in the SGZ, the composition of this region becomes primarily glial in nature during juvenile and adult stages. In order to examine this conclusion more directly, both methods, ${ }^{3} \mathrm{H}$-TdR-autoradiography and GFAP immunocytochemistry, were combined in the same specimen for light microscopic analysis.

In the animal injected with ${ }^{3} \mathrm{H}-\mathrm{TdR}$ at 5 months and sacrified 5 weeks later, 2 types of radiolabeled cells were found in the SGZ. One population, which was small $(5-7 \mu \mathrm{m})$, was double- 


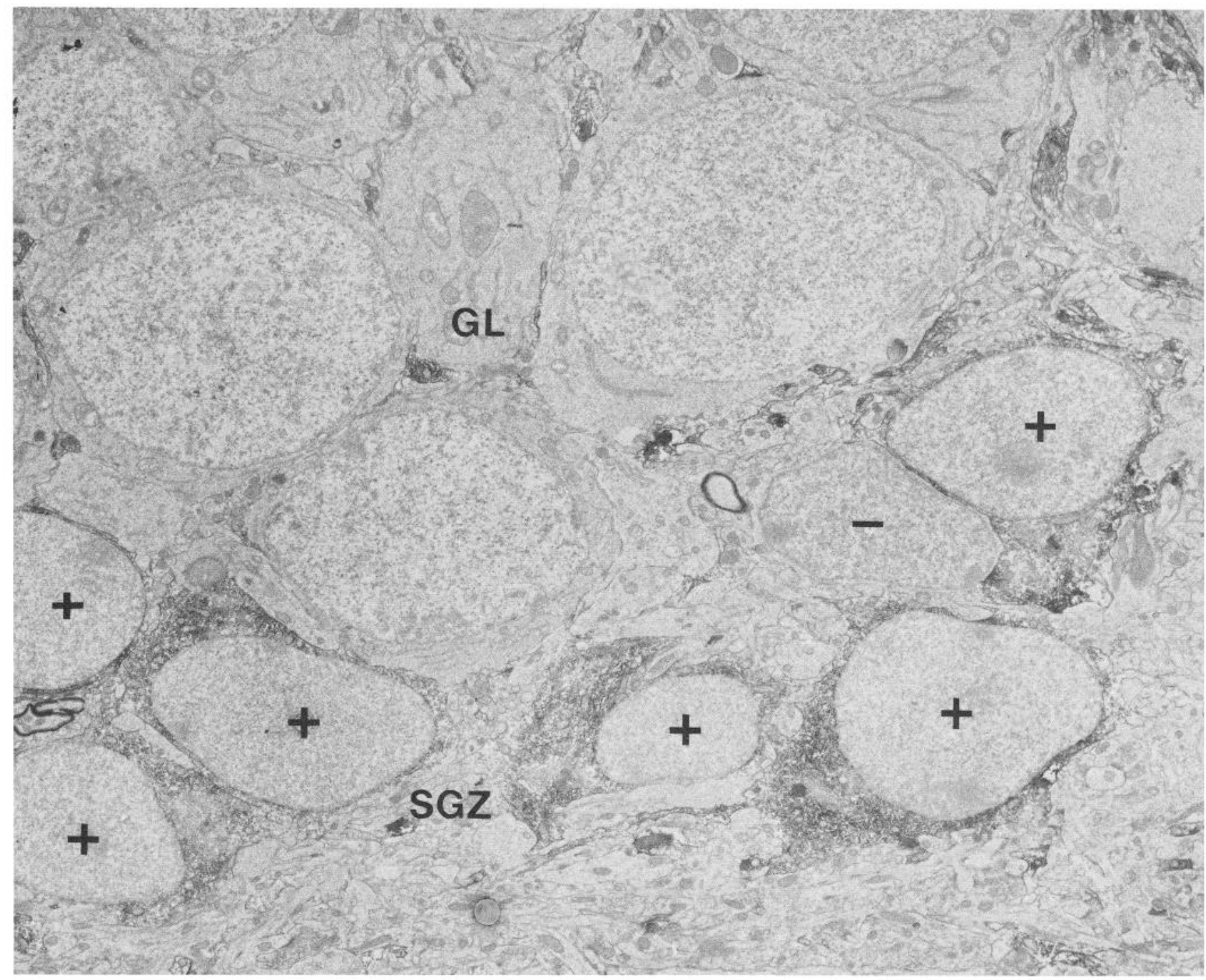

Figure 8. Ultrastructural localization of GFAP in the P184 specimen indicates that GFAP-positive (+) cells located in the subgranular zone (SGZ) are smaller and darker than the neurons in the granule cell layer $(G L)$, and their nuclei have a more homogeneous appearance. Other small cells in the SGZ are GFAP-negative $(-)$ and appear morphologically similar to the GFAP-positive cells. $\times 5000$.

labeled by both GFAP and ${ }^{3} \mathrm{H}-\mathrm{TdR}$ (Fig. $4 C$ ). The other doublelabeled population consisted of small $(5-7 \mu \mathrm{m})$, darkly stained GFAP-negative cells, suggesting that some nonastrocytic cells were also produced during this period (Fig. $4 D$ ). None of the radiolabeled cells that were immunonegative had neuronal characteristics at the light microscopic level. This conclusion was further corroborated by electron microscopy (see below).

Combined autoradiography and immunocytochemistry in $1 \frac{1}{2}-$ and 5-year-old specimens demonstrated that all of the cells generated in the SGZ at these ages are non-neuronal in nature, although not all of them reacted positively with the GFAP antisera (Figs. $5 B ; 6, B$ and $C$ ). The doubly radiolabeled and immunopositive cells were small $(5-7 \mu \mathrm{m})$ cells of the SGZ. The ${ }^{3} \mathrm{H}-\mathrm{TdR}$ labeled cells that are GFAP-negative were also small (5-7 $\mu \mathrm{m})$, darkly stained, and more characteristic of oligodendroglia or microglia than neurons. An occasional radiolabeled cell was found in the molecular layer adjacent to a blood vessel (Fig. 6D). It is unlikely that any of these cells are undifferentiated neurons, since the time of 2-3 months that elapsed between injections and sacrifice allows expression of cell characteristics (Rakic, 1973).

\section{Autoradiography, immunocytochemistry, and electron microscopy}

As a final step to determine the phenotype of the late-generated cells in the SGZ, we combined autoradiography, immunocytochemistry, and electron microscopy. This approach proved to be time-consuming and yielded a relatively small number of intensely ${ }^{3} \mathrm{H}-\mathrm{TdR}$ labeled cells. We examined 120 ultrathin semiserial sections from selected areas in each of animals aged 6 months and $1 \frac{1 / 2}{2}$ and 5 years. The exposure of photosensitive emulsion to tissue sections ranged from 6 to 18 months.

Radiolabeled cells were very rarely found in the SGZ, and it was therefore a considerable task to find a dozen cells that could be confidently identified as radiolabeled. Among these, 6 were GFAP-positive (Figs. 11 $A, 12 A$ ). Amidst the immunoreactive product, one could discern well-developed Golgi apparatus and relatively short cisternae of rough endoplasmic reticulum. Fil- 


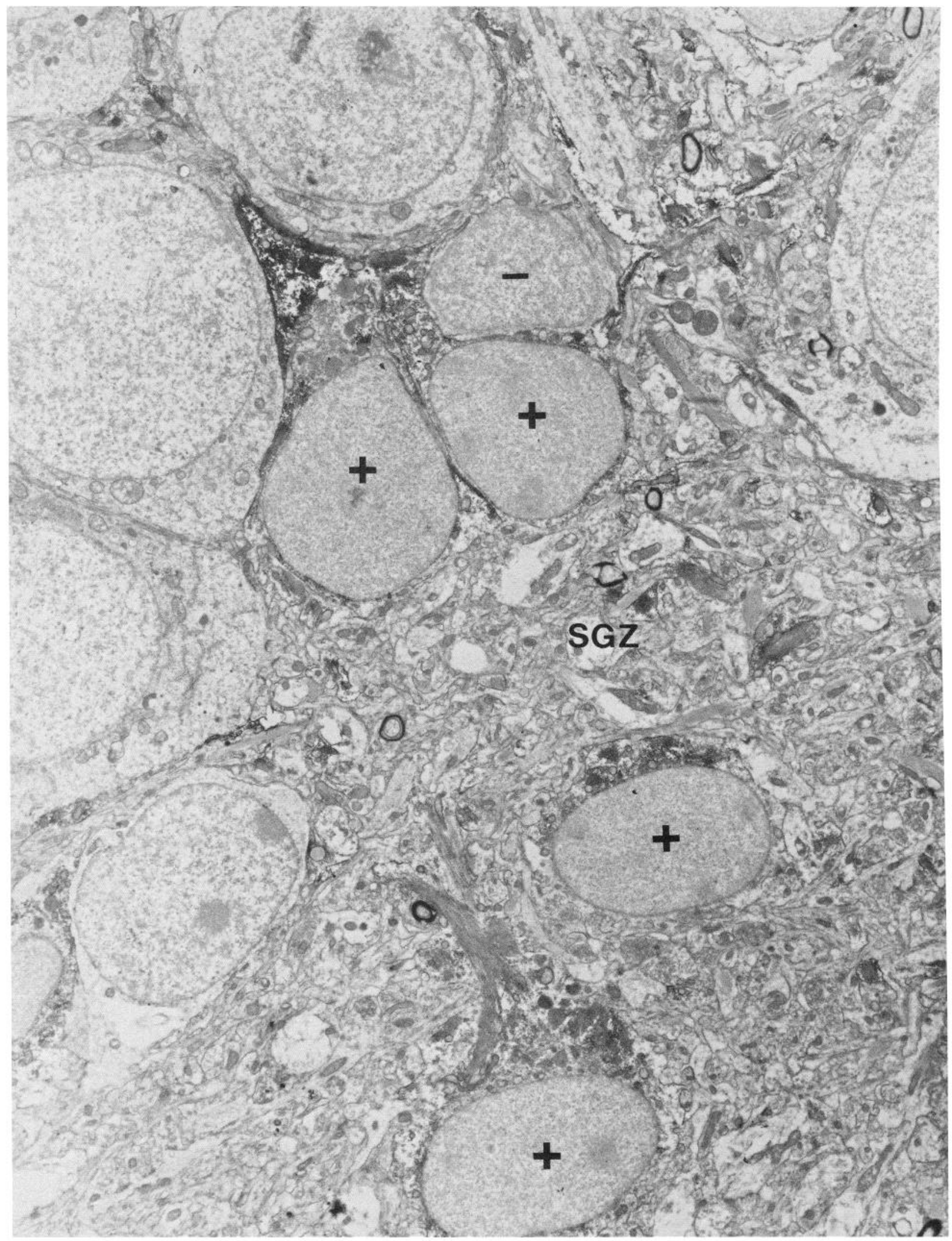

Figure 9. Ultrastructural localization of GFAP in the 11/2-year-old monkey reveals that the majority of small, dark cells in the SGZ are GFAPpositive $(+)$, with some small cells remaining GFAP-negative $(-) . \times 5000$. 


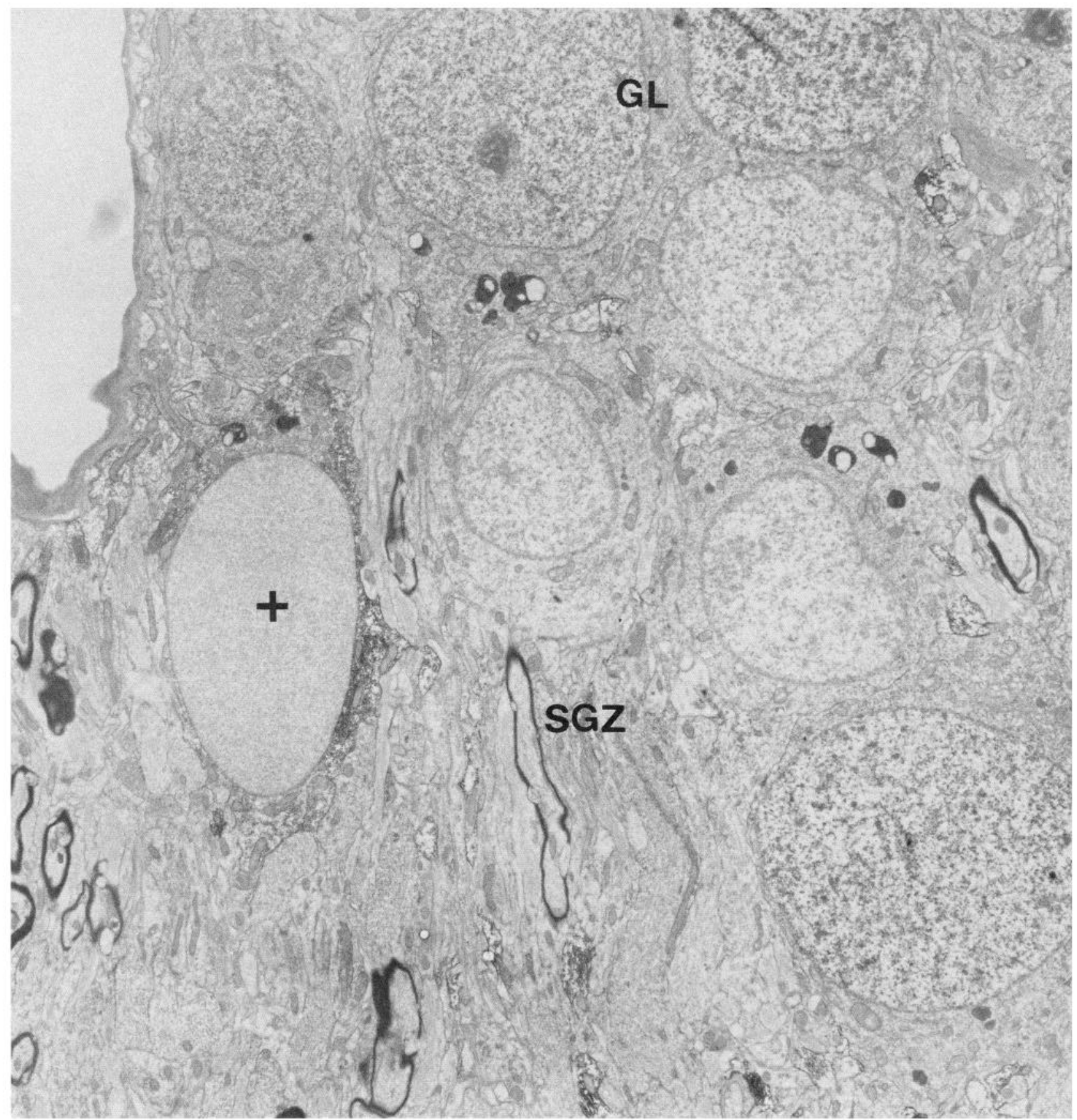

Figure. 10. Ultrastructural examination of the subgranular zone (SGZ) in the 5-year-old monkey for the immunocytochemical localization of GFAP reveals the presence of darkly stained GFAP-positive (+) cells. Many large, pale-staining granule cell neurons can be seen in the granule cell layer $(G L) . \times 5000$.

aments were more difficult to visualize because of heavy deposition of HRP granules. There was, however, no problem in identifying these cells as astrocytes. The GFAP-negative radiolabeled nuclei were smaller (4-5 $\mu \mathrm{m}$ nuclear diameter) and had clumps of irregularly distributed electron-dense chromatin with particularly thick condensation along the nuclear membrane. The nuclei were encircled by a thin rim of cytoplasm, which at times could be seen protruding into surrounding neuropil, giving these cells irregular contours. The distribution and pattern of rough endoplasmic reticulum and the relatively high electron density of cytoplasmic matrix gave these GFAP-neg- ative cells the appearance of resting microglial (Fig. 11, $B-D$ ) or oligodendroglial cell types (Fig. $12 B$ ). Finally, a third type of radiolabeled cell (also GFAP-negative) had ultrastructural features of proliferative, precursor cells and could be observed in the subgranular zone during the entire life span. Although utilization of immunocytochemistry does not preclude the possibility that some of the radiolabeled GFAP-negative cells did not react with antiserum for technical reasons, it is nevertheless significant that none of the ${ }^{3} \mathrm{H}$-TdR-labeled cells established synapses or had any other ultrastructural characteristics commonly considered as neuronal. 

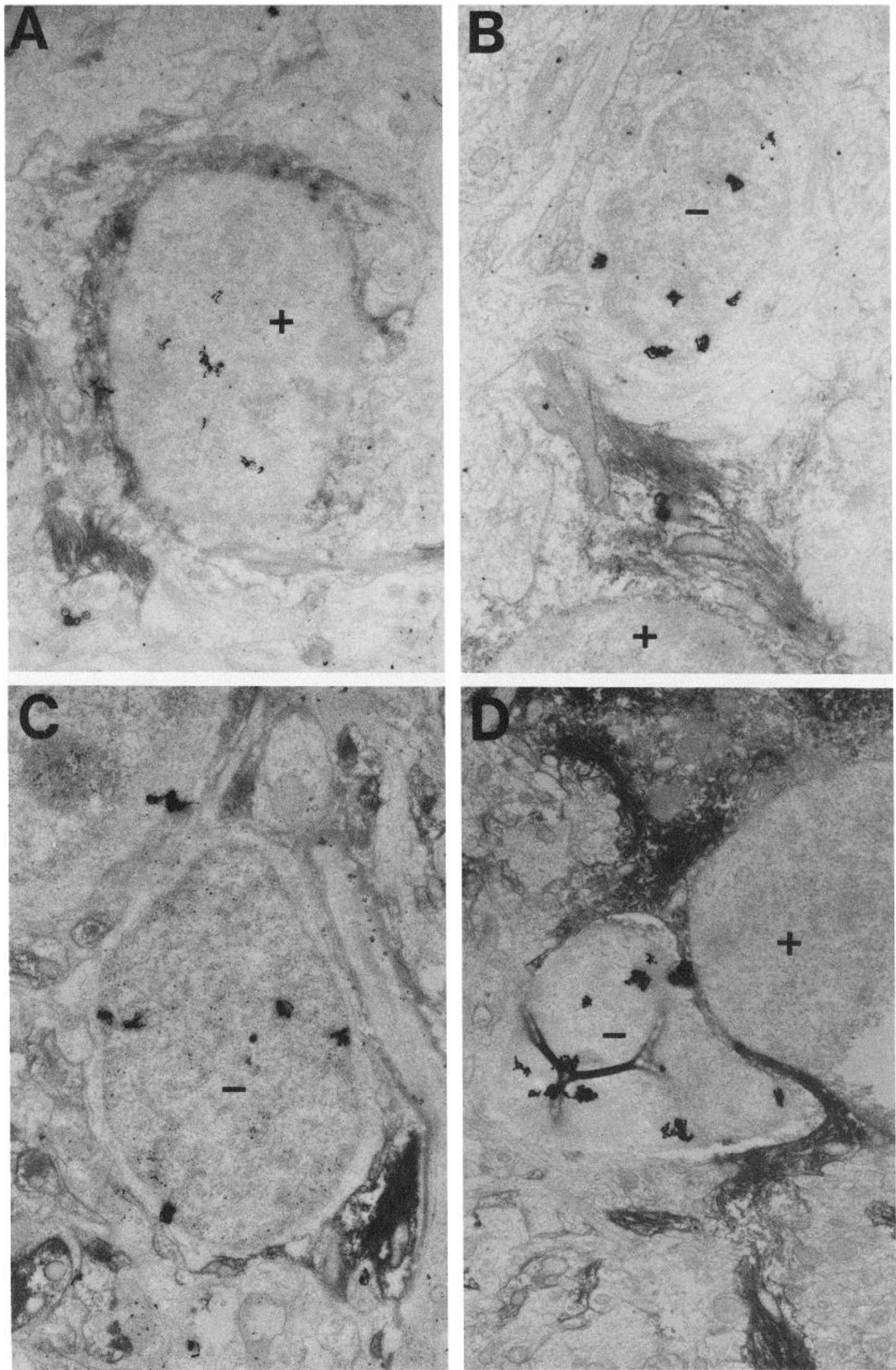

Figure 11. Ultrastructural characterization of the SGZ using combined immunocytochemical localization of GFAP and ${ }^{3} \mathrm{H}$-thymidine autoradiography in the $1 \frac{1}{2}$-year-old monkey. $A$, Six silver grains over this GFAP-positive (+) astroglial cell. $\times 10,000$. B, A small GFAP-negative $(-)$ cell with 7 silver grains beside a larger GFAP-positive $(+)$ glial cell. $\times 17,800$. $C$, A GFAP-negative $(-)$ cell with 5 silver grains. $\times 12,500 . D$, A more heavily labeled GFAP-negative $(-)$ cell closely apposed to a GFAP-positive $(+)$ cell. $\times 10,000$. No synapses were seen on any of these cells at higher magnification or in semiserial sections. 

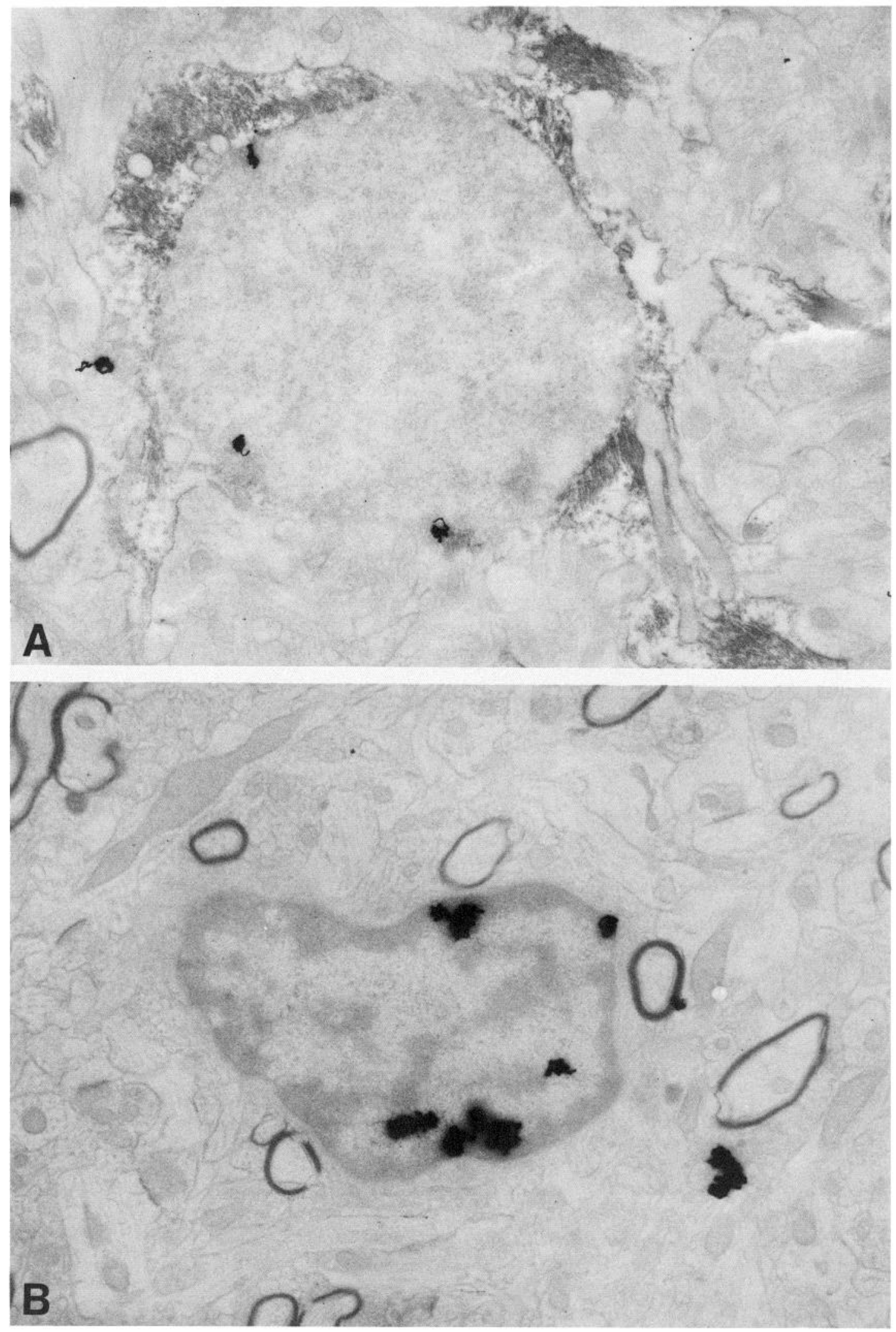

Figure 12. Ultrastructural characterization of the SGZ in the 5-year-old adult monkey. $A$, Radiolabeled, GFAP-positive astroglial cell in the SGZ in the monkey given 7 successive doses of ${ }^{3} \mathrm{H}-\mathrm{TdR}$. The cell has typical ultrastructural characteristics of an astrocyte including immunoreactivity to GFAP in the cytoplasma. $\times 13,200 . B$, Radiolabeled resting microglia in the SGZ. The cell shows an irregularly shaped, small nucleus with dark, lumpy heterochromatin, and a small amount of perinuclear cytoplasm. $\times 18,000$. 


\section{Discussion}

Cessation of neurogenesis in the dentate gyrus

The time of neuron origin in the hippocampal formation has been previously studied in a variety of mammalian species. However, the exact time point when neurogenesis in the dentate gyrus stops, or even whether it ever stops, has not been established unequivocally. Studies using the ${ }^{3} \mathrm{H}-\mathrm{TdR}$ autoradiographic method have demonstrated that the majority of neurons destined for the dentate gyrus, as in other parts of the CNS, are generated within a well-defined time period. Although the length of this period varies among species, there is general agreement that granule cells of the dentate gyrus, together with the granule cells of the olfactory bulb and cerebellum, are the last neurons produced in the mammalian CNS (for references, see Sidman and Rakic, 1982). There is, however, some confusion in the literature arising from the fact that the time of onset, peak period, and cessation of neurogenesis in relation to the time of birth varies significantly among mammals. For example, the genesis of dentate gyrus granule cells is a predominantly postnatal event in mice and rats (Angevine, 1965; Altman and Das, 1965; Altman and Bayer, 1975; Schlessinger et al., 1975), whereas in rabbits, cats, and rhesus monkeys, it occurs to a much larger extent before birth and lasts for various time periods postnatally (Gueneau et al., 1979, 1982; Rakic and Nowakowski, 1981; Wyss and Sripanidkulchai, 1985). The prenatal phase of neurogenesis is particularly pronounced in primates, including humans, which are born more mature than rodents. For example, it has been estimated that about $80 \%$ of granule cells in the rhesus monkey are generated before birth (Rakic and Nowakowski, 1981). Although we do not have similar ${ }^{3} \mathrm{H}-\mathrm{TdR}$ autoradiographic data, comparative histological and cytological analyses indicate that the dentate gyrus in humans also has a large prenatal phase of neurogenesis (Rakic and Sidman, 1968; Bogolepova, 1970; Sidman and Rakic, 1973, 1982; Kostovic, 1975; Purpura, 1975).

In the past few years, a number of reports have suggested that neurogenesis in the dentate gyrus continues throughout the entire life span of some rodent species. 'The evidence for perpetual neurogenesis was based either on labeling with ${ }^{3} \mathrm{H}-\mathrm{TdR}$ (Kaplan and Bcll, 1983, 1984; Crcspo ct al., 1986), or on ccll counts, which show a steady increase in the number of cells within the dentate gyrus (Bayer, 1985). However, there is considerable disagreement concerning the origin and nature of cells generated in the adult dentate gyrus. Suggestions for a source of new neurons have ranged from the undifferentiated stem cells, which seems reasonable, to the claim that fully mature synaptically connected granule neurons can divide (Kaplan and Bell, 1984). The magnitude of the number of newly generated granule cells in adulthood has also ranged widely in the literature, from a few to over a 1000 per day. Some of these numbers seem high considering the life span of rodents and the overall size of their dentate gyrus. It should be emphasized that the reported phenomenon of continued neurogenesis in adult rodents may be particularly prominent in rat strains that grow continually throughout their entire life span (Boss et al., 1985).

\section{Nature of late-generated cells in the SGZ of primates}

Although we could not detect any newly produced neurons in the dentate gyrus of adult rhesus monkeys, we regularly observed a certain number of intensely ${ }^{3} \mathrm{H}-\mathrm{TdR}$ labeled, presumably dividing cells in the SGZ. The level of proliferation within this zone is substantial during late embryonic ages and throughout infancy. However, it diminishes gradually during the juvenile period and becomes rather low by the time of puberty. Nevertheless, cell proliferation continues at a low level throughout the entire life span of the rhesus monkey. Our objective was to determine the nature of these newly generated cells in the adult. The results of combined autoradiographic and immunocytochemical analyses at both light and ultrastructural levels revealed that during infancy the production of neurons diminishes. As the number of neurons produced in the SGZ tapers off, the relative production of several types of glial cells gradually increases. Our data indicate that the SGZ generates exclusively non-neuronal cells in the adult.

The systematic changes in the proportions of cells produced occurs in parallel with changes in the composition of the proliferative cells in the SGZ. At early stages (e.g., prior to E58), the dentate gyrus receives neuronal and glial cells exclusively from the ventricular zone. During a middle period (between E58 and E90), both the ventricular and the SGZ contribute cells to this structure (Duffy and Rakic, 1983; Eckenhoff and Rakic, 1984). After the ventricular zone becomes depleted (i.e., after E90), cells (neurons and glia) destined for the dentate gyrus are produced in the SGZ (Nowakowski and Rakic, 1981; Eckenhoff and Rakic, 1983). During this last period the SGZ contains at least 2 types of precursors, one that produces neuronal and the other that produces non-neuronal cell lines. The latter may actually consist of 2 subtypes, one which produces astrocytes and the other oligodendroglia. However, the experimental procedure used does not allow us to distinguish between these 2 categories. Nevertheless, the present study shows that in the adult monkey, only the non-neuronal precursor cells must be active, since no neurons were produced.

The mitotic activity also persists in the SGZ of postnatal rats (Bayer and Altman, 1974; Schlessinger et al., 1975), guinea pigs (Altman and Das, 1967), rabbits (Gueneau et al., 1979), and cats (Wyss and Sripanidkulchai, 1985). However, the methods used in most of the previous studies could not provide a clear distinction between neuronal and non-neuronal cell lines. Thus, the initial suggestion that dividing cells in the adult hippocampus may be neurons should be viewed as speculative (Altman, 1962). Morc rccently, the ncuronal nature of late-generated cells in the dentate gyrus has been reported in the rat and rabbit (Kaplan and Hinds, 1977; Gueneau et al., 1982; Kaplan and Bell, 1983, 1984; Kaplan, 1985). The strongest evidence comes from the double-labeling method (axonal transport and ${ }^{3} \mathrm{H}-\mathrm{TdR}$ ) in the 3-month-old rat (Trice and Stanfield, 1986). However, although these reports provide supporting evidence that neurogenesis exists in the adult hippocampus, the actual documentation is based on infant, juvenile, and 2- to 3-month-old animals, which are still developing and growing. Thus, the neuronal nature of cells generated in older animals has not, so far, been directly demonstrated.

The existence of neurogenesis after birth, itself, is not a novel finding (Angevine, 1965) and is not confined to rodents or to the hippocampus (Sidman and Rakic, 1982). Our previous study in infant monkeys, for example, also indicates that a substantial number of granule cell neurons can be generated during the first 3 months after birth (Nowakowski and Rakic, 1981; Rakic and Nowakowski, 1981). However, according to these initial studies, postnatal neurogenesis tapers off at some point. The unusual finding, which has appeared in more recent reports of studies carried out in rats, was that neurogenesis in some areas may 
never stop. In contrast, our present results in the rhesus monkey reveal that the populations of neuronal and non-neuronal cells in the SGZ change continually during postnatal development in favor of glial cells, until no neuronal precursor can be detected. The possibility that some of the small, darkly stained, GFAPnegative cells that incorporated ${ }^{3} \mathrm{H}-\mathrm{TdR}$ in the postpubertal monkeys can under some conditions serve as precursors of any cell type, including neurons, cannot be totally excluded. Although precise classification into one or the other subtype of glial cell may be disputed, there is no doubt that they are nonneuronal in nature. Therefore, we conclude that in the healthy animals, under normal living conditions in the colony that were used in the present study, proliferative cells did not produce neurons. Our findings concur with the repeated evidence of a continuing genesis and turnover of the various types of glial cells (astrocytes, resting microglia, and dark oligodendroglia) that has been reported in other species (Privat, 1975; Landfield et al., 1981; Kitamura et al., 1984). Our conclusion of continuing gliogenesis is also in accord with the concept of a steady level of glial turnover in other brain structures in normal adult mammals (Smart and Leblond, 1961; Privat, 1975; Skoff, 1980; Ichikawa and Hirata, 1982; Korr et al., 1983). It should be emphasized, however, that the low and steady state of gliogenesis may be suddenly altered in response to mechanical trauma or other insults of various types and origins (Altman, 1962; Vaughn and Pease, 1970; Skoff et al., 1976; Ludwin, 1984). This steady state also changes at advanced age when the net increase in glial cells seems to be accompanied by concomitant neuronal loss (Landfield et al., 1977; Saploski et al., 1985).

\section{Methodological limits}

A conclusion based on "negative findings," such as the one presented here, requires some comment about the level of confidence and reliability of the data and a brief review of the possible pitfalls inherent in the methods employed. Unlike previous studies of this issue, we used several types of evidence and combined 4 methods to determine the nature and fate of dividing cells. The results indicate that in the rhesus monkey, the genesis of granule cells in the dentate gyrus stops sometime during the juvenile period. It was, however, more difficult to pinpoint the exact time when neurogenesis totally stops. Our previous estimate that neurogenesis is continuous throughout at least the third postnatal month (Rakic and Nowakowski, 1981 ) is correct but perhaps too conservative. This more rigorous examination of larger numbers of specimens extends the end point of neurogenesis to sometime between the fourth and sixth postnatal months. The present study still confirms, however, that neurogenesis does cease during the juvenile period. One should also emphasize that there may be a considerable individual or sex-related variability in timing of maturation. The establishment of an exact and statistical limit of neurogenesis was not the goal of our study. The most important goal was to examine a large number of serial sections in pubertal or postpubertal animals that have received several injections of ${ }^{3} \mathrm{H}$-TdR to test the presence of neurogenesis in adult primates. We failed to reveal a single heavily labeled cell with the unequivocal morphology of a neuron. This "negative" finding was upheld in repeated examinations, although a steady number of dividing cells in the SGZ has been observed throughout the life span. The presence of radiolabeled cells in the SGZ is an important point since it clearly demonstrates that ${ }^{3} \mathrm{H}-\mathrm{TdR}$ passes the blood-brain barrier in adult animals and is available for incorporation in dividing cells in the CNS (see also Rakic, 1985b). The use of electron microscopy and immunocytochemistry consistently reveals the non-neuronal nature of the radiolabeled cells as they could all be classified as stem cells or as various glial or endothelial cells. Finally, it is unlikely that our results are influenced by seasonal fluctuations, since injections have been given during 11 out of the 12 months of the year.

A crucial question seems to be whether one can exclude the possibility that we have missed some labeled neurons due to the sampling method. In an attempt to decrease this possibility, we examined a large number of autoradiograms, and, in addition, some animals had been given multiple injections of ${ }^{3} \mathrm{H}$ TdR. The number of injections was limited to between 3 and 7 in an attempt to avoid incorporation of ${ }^{3} \mathrm{H}-\mathrm{TdR}$ during repair of nuclear DNA. Larger amounts of circulating radioisotopes can produce damage to the DNA, whose repair, utilizing newly injected thymidine, could cause radioactivity of the nucleus without cell division (Kunzle, 1985; Rapp et al., 1985). However, the total of 16 injections to the 4 adult animals (Table 1) may be considered as equivalent to 16 independent labeling experiments (Rakic, 1985b). Therefore, if labeled neurons in any of these animals exist but we have missed them, their number must be very small. Furthermore, the brief interval between ${ }^{3} \mathrm{H}-\mathrm{TdR}$ injections and sacrifice used in some of our experiments has reduced the unlikely possibility that newly generated neurons have been missed because of degeneration prior to sacrifice. Finally, the absence of newly generated neurons in the dentate gyrus is in harmony with the absence of intensively radiolabeled neurons in similar studies of over 20 other structures and a large variety of neuronal types of the adult rhesus monkey brain (Rakic, 1973, 1974, 1977, 1985a, b; Lenn et al., 1978; Brand and Rakic, 1979, 1980; Cooper and Rakic, 1981; Gould and Rakic, 1981; Rakic and Nowakowski, 1981; Ogren and Rakic, 1981; Levitt and Rakic, 1982; LaVail et al., 1983).

\section{Stable population of neurons in primates may be a biological necessity}

Although adult primates are characterized by a stable population of neurons (Rakic, 1985a, b), a limited level of neurogenesis continues throughout the entire life span of certain nonmammalian species. For example, neurogenesis has been described in adult amphibians (Kirsche, 1967), fish (Raymond and Easter, 1983), and birds (Burd and Nottebohm, 1985; Nottebohm, 1985). Based on these studies carried out in submammalian species, and on the reports of neurogenesis in the hippocampus of adult rats (Kaplan and Bell, 1984; Bayer, 1985; Kaplan et al., 1985), it has been proposed that continuing neurogenesis may also exist in the human brain (Kaplan, 1985; Nottebohm, 1985; see also Kolata, 1984). This speculation has led to the hypothesis that the addition of neurons may play an important role in learning and memory (Kaplan and Bell, 1984; Nottebohm, 1984, 1985). In light of our finding that neurogenesis seemingly does not continue in the hippocampus of the adult rhesus monkey, this possibility is rather unlikely. Even if neurogenesis has been missed as a result of methodological limitations (see above), the number of newly generated neurons in adult primates must be very small, and thus hardly comparable to the massive levels of neurogenesis reported in hirds or rodents. Furthermore, according to the proposed role of new cells in learning, one would expect an even higher level of neurogenesis to occur in primates, considering their larger capacity for these functions. It is interesting, however, that in the rodent dentate gyrus, continued neurogenesis 
in the adult has been repeatedly reported, and, therefore, there may be genuinc spccics-spccific differences. However, the apparent difference between the results in rodents and primates may be partially explained by variations in the definition of "adult," which in some studies was used to describe 2-monthold sexually active but still growing rodents (e.g., Kaplan and Hinds, 1977; Kaplan and Bell, 1984). If the massive postnatal neurogenesis in the dentate gyrus of fully mature, over 1-yearold rats is proven to exist, one must then conclude that the primate hippocampus is, in this important respect, different from the hippocampus of rodents.

The biological significance of the stable population of neurons in adult organisms and confinement of neurogenesis to the developing period in primates has been discussed elsewhere (Rakic, $1985 \mathrm{a}, \mathrm{b}$ ). Our present findings support the concept that neurogenesis is limited to the developmental period, even though this period extends well into postnatal life. Analysis of the adult, postpubcrtal monkey reveals structural stability in the primatc dentate gyrus, which is considered by many to be involved in the retrieval of memory in this species (e.g., Mahut et al., 1982; Squire and Zola-Morgan, 1983). Neurons that last for the entire life span preserve access to acquired information for decades and in some individuals over a century. In this respect, it may be significant that the developmental phase of synaptic elimination in the dentate gyrus, as in the other structures of the monkey cerebrum, starts only after the phase of neurogenesis has been completed (Rakic, et al., 1986). One is tempted to speculate that a stable population of neurons is an essential factor for proper retrieval and preservation of acquired information. This information may be imprinted in the synaptic connections of granule cells (e.g., Lynch and Baudry, 1984). A turnover of dentate gyrus granule cells during adulthood would perhaps be a disadvantage, rather than asset, since newly generated cells that take the place of the old ones may not have the benefit of any of the previous training or experience. A stable population of neurons, therefore, may be a biological necessity in an organism whose survival relies on the learned behavior acquired over a long period of time (Rakic, 1985a).

\section{References}

Altman, J. (1962) Are neurons formed in the brains of adult mammals? Science 135: 1127-1128.

Altman, J. (1963) Autoradiographic investigation of cell proliferation in the brains of rats and cats. Anat. Rec. 145: 573-592.

Altman, J., and S. Bayer (1975) Postnatal development of the hippocampal dentate gyrus under normal and experimental conditions. In The Hippocampus, Vol. 1, Structure and Development, R. L. Issacson and K. H. Pribram, eds., pp. 95-122, Plenum, New York.

Altman, J., and G. Das (1965) Autoradiographic and histological evidence of postnatal hippocampal neurogenesis in rats. J. Comp. Neurol. 124: 319-336.

Altman, J., and G. Das (1967) Postnatal neurogenesis in the guinea pig. Nature 214: 1098-1101.

Angevine, J. B., Jr. (1965) Time of neuron origin in the hippocampal region. An autoradiographic study in the mouse. Exp. Neurol. 2: 117.

Bayer, S. A. (1982) Changes in the total number of dentate granule cells in juvenile and adult rats: A correlated volumetric and ${ }^{3} \mathrm{H}$-thymidine autoradiographic study. Exp. Brain Res. 46: 315-323.

Bayer, S. A. (1985) Neuron production in the hippocampus and olfactory bulb of the adult rat brain: Addition or replacement? Ann. NY Acad. Sci. 457: 163-172.

Bayer, S. A., and J. Altman (1974) Hippocampal development in the rat: Cytogenesis and morphogenesis examined with autoradiography and low-level x-irradiation. J. Comp. Neurol. 158: 55-80.

Bayer, S. A., J. W. Yakel, and P. S. Puri (1982) Neurons in the rat dentate gyrus granular layer substantially increase during juvenile and adult life. Science 216: 890-892.

Bogolepova, I. N. (1970) Structure and development of the human hippocampus in prenatal ontogenesis. Neurosci. Trans. 16:56-62.

Boss, B., G. M. Peterson, and W. M. Cowan (1985) On the number of neurons in the dentate gyrus of the rat. Brain Res. 338: 144-150.

Brand, S., and P. Rakic (1979) Genesis of the primate neostriatum: $\left[{ }^{3} \mathrm{H}\right]$-thymidine autoradiographic analysis of the time of neuron origin in the rhesus monkey. Neuroscience 4: 767-778.

Brand, S., and P. Rakic (1980) Neurogenesis of the nucleus accumbens septi and neighboring septal nuclei in the rhesus monkey: A combined ${ }^{3} \mathrm{H}$-thymidine and electron microscopic study. Neuroscience $5: 2125-$ 2138.

Burd, G. D., and F. Nottebohm (1985) Ultrastructrual characterization of synaptic terminals formed on newly generated neurons in a song central nucleus of the adult canary forebrain. J. Comp. Neurol. 240: $143-152$.

Caviness, V. S., Jr. (1973) Time of neuron origin in the hippocampus and dentate gyrus of normal and reeler mutant mice: An autoradiographic analysis. J. Comp. Neurol. 151: 113-120.

Choi, B. H. (1986) Glial fibrillary acidic protein in radial glia of early human fetal cerebrum: A light and electron microscopic immunoperoxidase study. J. Neuropathol. Exp. Neurol. 45: 408-418.

Cooper, M. L., and P. Rakic (1981) Neurogenetic gradients in the superior and inferior colliculi of the rhesus monkey. J. Comp. Neurol. 202: 309-334.

Crespo, D., B. B. Stanfield, and W. M. Cowan (1986) Evidence that late-generated granule cells do not simply replace earlier formed neurons in the rat dentate gyrus. Exp. Brain Res. 62: 541-548.

Duffy, C. J., and P. Rakic (1983) Differentiation of granule cells in the dentate gyrus of the rhesus monkey: A quantitative Golgi study. J. Comp. Neurol. 214: 225-332.

Eckenhoff, M. F., and P. Rakic (1983) Composition of the proliferative subgranular zone of the developing and mature dentate gyrus in the rhesus monkey: EM-immunocytochemical (anti-GFAP) and autoradiographic ( $\left.{ }^{3} \mathrm{H}-\mathrm{TdR}\right)$ analyses. Soc. Neurosci. Abstr. 9: 900.

Eckenhoff, M. F., and P. Rakic (1984) Radial organization of the hippocampal dentate gyrus: A Golgi, ultrastructural and immunocytochemical analysis in the developing rhesus monkey. J. Comp. Neurol. 223: 1-21.

Eng, L. F., and L. J. Rubinstein (1978) Contribution of immunohistochemistry to diagnostic problems of human cerebral tumors. J. Histochem. Cytochem. 26: 513-522.

Gould, B. B., and P. Rakic (1981) The total number, time of origin and kinetics of proliferation of neurons comprising the deep cerebellar nuclei in the rhesus monkey. Exp. Brain Res. 44: 195-206.

Gueneau, G., J. Drouet, A. Privat, and L. Court (1979) Differential radiosensitivity of neurons and neuroglia of the hippocampus in the adult rabbit. Acta Neuropathol. 48: 199-209.

Gueneau, G., A. Privat, J. Drouet, and L. Court (1982) Subgranular zone of the dentate gyrus of young rabbits as a secondary matrix. A high resolution autoradiographic study. Dev. Neurosci. 5: 345-358.

Ichikawa, M., and Y. Hirata (1982) Morphology and distribution of postnatally generated glial cells in the somatosensory cortex of the rat: An autoradiographic and electron microscopic study. Dev. Brain Res. 4: 369-377.

Kaplan, M. S. (1985) Formation and turnover of neurons in young and senescent animals: An electronmicroscopic and morphometric analysis. Ann. NY Acad. Sci. 457: 173-192.

Kaplan, M. S., and D. H. Bell (1983) Neuronal proliferation in the 9-month-old rodent-Radioautographic study of granule cells in the hippocampus. Exp. Brain Res. 52: 1-5.

Kaplan, M. S., and D. H. Bell (1984) Mitotic neuroblasts in the 9-dayold and 11-month-old rodent hippocampus. J. Neurosci. 4: 14291441.

Kaplan, M. S., and J. W. Hinds (1977) Neurogenesis in the adult rat: Electron microscopic analysis of light radioautographs. Science 197: 1092-1094.

Kaplan, M. S., N. A. McNelly, and J. W. Hinds (1985) Population dynamics of adult-formed granule neurons of the rat olfactory bulb. J. Comp. Neurol. 239: 117-125.

Kirsche, W. (1967) Uber postembryonale matrix zonen in Gehirn verschiedener Vertebrate und deren Beziehung zur Hirnbauplanlehre. Z. Mikrosk. Anat. Forsch. 77: 313-406.

Kitamura, T., T. Miyake, and S. Fujita (1984) Genesis of resting 
microglia in the gray matter of mouse hippocampus. J. Comp. Neurol. 226: $421-433$.

Kolata, G. (1984) New neurons form in adulthood. Science 224: 13251326.

Korr, H., W.-D. Schilling, B. Schultze, and W. Mauer (1983) Autoradiographic studies of glial proliferation in different areas of the brain of the 14-day-old rat. Cell Tissue Kinet. 16: 393-413.

Kostovic, I. (1975) The correlation between distribution of synapses and Nissl-Golgi architectonics in hippocampus of 15 week human fetus. Anat. Rec. 181: 536.

Kunzle, C. C. (1985) Enzymology of DNA replication and repair in the brain. Brain Res. Rev. 10: 231-245.

Landfield, P. W., G. Rose, L. Sandles, T. Wohlstadter, and G. Lynch (1977) Pattern of astroglial hypertrophy and neuronal degeneration in the hippocampus of aged, memory-deficient rats. J. Gerontol. 32: 3-12.

Landfield, P. W., L. D. Brown, T. A. Pitler, J. D. Lindsey, and G. Lynch (1981) Hippocampal aging in rats: A morphometric study of multiple variables in semithin sections. Neurobiol. Aging 2: 265-275.

LaVail, M. M., D. Yasumura, and P. Rakic (1983) Cell genesis in the rhesus monkey retina. Invest. Ophthal. Vis. Sci. (Suppl.) 24: 7.

Lenn, N. J., N. Halfon, and P. Rakic (1978) Development of interpeduncular nucleus in rhesus monkey and human. Anat. Embryol. 125: 273-289.

Levitt, P. R., and P. Rakic (1980) Immunoperoxidase localization of glial fibrillary acid protein in radial glial cells and astrocytes of the developing rhesus monkey brain. J. Comp. Neurol. 193: 815-840.

Levitt, P. R., and P. Rakic (1982) The time of genesis, embryonic origin and differentiation of the brain stem monoamine neurons in the rhesus monkey. Dev. Brain Res. 4: 35-57.

Levitt, P., M. L. Cooper, and P. Rakic (1981) Coexistence of neuronal and glial precursor cells in the cerebral ventricular zone of the fetal monkey: An ultrastructural immunoperoxidase analysis. J. Neurosci. 1: 27-39.

Levitt, P., M. L. Cooper, and P. Rakic (1983) Early divergence and changing proportions of neuronal and glial precursor cells in the primate cerebral ventricular zone. Dev. Biol. 96: 472-484.

Ludwin, S. K. (1984) Proliferation of mature oligodendrocytes after trauma to the central nervous system. Nature 308: 274-275.

Lynch, G., and M. Baudry (1984) The biochemistry of memory: A new and special hypothesis. Science 224: 1057-1063.

Mahut, H., S. Zola-Morgan, and M. Moss (1982) Hippocampal resections impair associative learning and recognition memory in the monkey. J. Neurosci. 2: 1214-1229.

Nottebohm, F. (1984) Vocal learning and its possible relation to replacable synapses and neurons. In Biological Perspective on Language, D. Caplan, A. R. Lecours, and A. Smith, eds., pp. 65-95, MIT Press, Cambridge, MA.

Nottebohm, F. (1985) Neuronal replacement in adulthood. Ann. NY Acad. Sci. 457: 143-161.

Nowakowski, R. S., and P. Rakic (1979) The mode of migration of neurons to the hippocampus: A Golgi and electron microscopic analysis in fetal rhesus monkey. J. Neurocytol. 8: 697-718.

Nowaknwski, R. S., and P. Rakic (1981) The site of origin and route and rate of migration to the hippocampal region of the rhesus monkey. J. Comp. Neurol. 196: 129-154.

Ogren, M. P., and P. Rakic (1981) The prenatal development of the pulvinar in the monkey ${ }^{3} \mathrm{H}$-thymidine autoradiographic and morphometric analyses. Anat. Embryol. 162: 1-20.

Privat, A. (1975) Postnatal gliogenesis in the mammalian brain. Int. Rev. Cytol. 40: 281-323.

Purpura, D. (1975) Dendritic differentiation in human cerebral cortex: Normal and abnormal developmental pattern. Adv. Neurol. 12: 141169.

Rakic, P. (1973) Kinetics of proliferation and latency between final division and onset of differentiation of the cerebellar stellate and basket neurons. J. Comp. Neurol. 147: 523-546.

Rakic, P. (1974) Neurons in rhesus monkey visual cortex: Systematic relation between time of origin and eventual disposition. Science 183 : $425-427$.
Rakic, P. (1975) Timing of major ontogenetic events in the visual cortex of the rhesus monkey. In Brain Mechanisms in Mental Retardation, N. A. Buchwald and M. Brazier, eds., pp. 3-40, Academic, New York.

Rakic, P. (1977) Genesis of the dorsal lateral geniculate nucleus in the rhesus monkey: Site and time of origin, kinetics of proliferation, routes of migration and pattern of distribution of neurons. J. Comp. Neurol. 176: 23-52.

Rakic, P. (1981) Neuronal-glial interaction during brain development. Trends Neurosci. 4: 184-187.

Rakic, P. (1985a) Limits of neurogenesis in primates. Science 227: $154-156$.

Rakic, P. (1985b) DNA synthesis and cell division in the adult primate brain. Ann. NY Acad. Sci. 457: 193-211.

Rakic, P., and R. S. Nowakowski (1981) The time of origin of neurons in the hippocampal region of the rhesus monkey. J. Comp. Neurol. 196: 99-128.

Rakic, P., and R. L. Sidman (1968) Supravital DNA synthesis in the developing human and mouse brain. J. Neuropathol. Exp. Neurol. 27: $246-276$.

Rakic P., J.-P. Bourgeois, M. F. Eckenhoff, N. Zecevic, and P. S. Goldman-Rakic (1986) Concurrent overproduction of synapses in diverse regions of the primate cerbral cortex. Science 232: 232-235.

Rapp, L. M., J. G. Jose, and D. G. Pitts (1985) DNA repair synthesis in the rat retina following in vivo exposure to $300 \mathrm{~nm}$ radiation. Invest. Ophthal. Vis. Sci. 26: 384-388.

Raymond, P. A., and S. S. Easter, Jr. (1983) Postembryonic growth of the optic tectum in goldfish. I. Location of germinal cells and numbers of neurons produced. J. Neurosci. 3: 1077-1091.

Saploski, R. M., L. C. Krey, and B. S. McEwen (1985) Prolonged glucocorticoid exposure reduces hippocampal neuron number: Implications for aging. J. Neurosci. 5: 1222-1227.

Schlessinger, A. R., W. M. Cowan, and D. I. Gottlieb (1975) An autoradiographic study of the time of origin and the pattern of granule cell migration in the dentate gyrus of the rat. J. Comp. Neurol. 159: 149-176.

Sidman, R. L., and P. Rakic (1973) Neuronal migration, with special reference to developing human brain: A review. Brain Res. 62: 1-35.

Sidman, R. L., and P. Rakic (1982) Development of the human central nervous system. In Cytology and Cellular Neuropathology, 2nd ed. pp. 3-145, C. C. Thomas, Springfield, IL.

Skoff, R. P. (1980) Neuroglia: A reevaluation of their origin and development. Pathol. Res. Pract. 168: 279-300.

Skoff, R. P., D. L. Price, and A. Stocks (1976) Electron microscopic autoradiographic studies of gliogenesis in the rat optic nerve. Time of origin. J. Comp. Neurol. 169: 313-334.

Smart, I., and C. P. Leblond (1961) Evidence for division and transformations of neuroglia cells in the mouse brain, as derived from radioautography after injection of thymidine- $\mathrm{H}^{3}$. J. Comp. Neurol. 116: 349-367.

Squire, L. R., and S. Zola-Morgan (1983) The neurology of memory: The case for correspondence between the findings for human and nonhuman primates. In The Physiological Basis of Memory, J. A. Deutsch, ed., pp. 199-268, Academic, New York.

Telford, J. N., and F. Matsumura (1969) The expandable loop: An improved wire-loop device for producing thin photographic film suited for autoradiography electron microscopy. Stain Technol. 44: 259260.

Trice, J. E., and B. B. Stanfield (1986) Evidence for the generation in adult rat dentate gyrus of neurons which extend axonal projections. Ann. Neurol. 20: 392.

Vaughn, J. E., and D. C. Pease (1970) Electron microscopic studies of Wallerian degeneration in rat optic nerve. II. Astrocytes, oligodendrocytes and adventitial cells. J. Comp. Neurol. 140: 207-226.

Wyss, M., and B. Sripanidkulchai (1985) The development of Ammon's horn and fascia dentata in the cat: $\mathrm{A}\left[{ }^{3} \mathrm{H}\right]$ thymidine analysis. Dev. Brain Res. 18: 185-198. 